\title{
Gudbilledlighed og syndefald: Aspekter af Grundtvigs og Kierkegaards menneskesyn på baggrund af Irenæus
}

\author{
Af Niels Jørgen Cappelørn
}

I sit menneskesyn skelner Irenæus mellem Guds billede og Guds lighed. Ved syndefaldet bevarer mennesket billedet i sjælen, mens ligheden i ånden går tabt og skal genfødes ved Guds Ånd. Med Irenæus som folie afdækkes sider af Grundtvigs og Kierkegaards syn på mennesket i forhold til syndefaldets følger for gudbilledligheden. De deler den opfattelse, at mennesket består af legeme, sjæl, ånd, og at det bærer et skabelsesgivet guddommeligt præg, som ikke er totalt forgået, når det gælder Guds billede, men tabt, når det gælder Guds lighed. For Grundtvig er der bevaret noget positivt af gudbilledet i sjælen i form af genlydsordet; for Kierkegaard er der efterladt noget negativt af gudbilledet i sjælen i form af en splittet frihed, som dog positivt bliver til syndsbevidsthed og trang efter Gud. Det er Guds Ånd, der virker fornyelsen af gudbilledet og genfødelsen af gudligheden, hos Grundtvig i dåben, hos Kierkegaard i et samspil mellem skriftemål og nadver. Der er ikke tale om nyskabelse, men om fornyelse, genfødelse, gentagelse og genforening $\mathrm{i}$ ånd og sandhed. Grundtvig, der især tænker dynamisk, fremhæver den ensartede kvalitet, Kierkegaard, der mere tænker dialektisk, pointerer den forskelligartede kvalitet henholdsvis før og efter fornyelsen og genfødelsen.

Det er artiklens tese, at den oldkirkelige teolog Irenæus' distinktion mellem imago dei og similitudo dei ud fra beretningen i Første Mosebog om menneskets skabelse i Guds billede og lighed (1,26-27) lader sig efterspore hos N. F. S. Grundtvig og Søren Kierkegaard, og at det åbner mulighed for at afdække nye aspekter og påvise parallelle synspunkter i Grundtvigs og Kierkegaards menneskesyn, hvad angår forholdet mellem menneskets gudbilledlighed og dets syndefald.

Da mit kendskab til Kierkegaard beror på mange års læsning af hans tekster, mens min indlæsning i Grundtvigs er af nyere dato, indrømmer jeg forlods, at det medfører den hermeneutiske skævhed, at min omgang med den grundtvigske terminologi uundgåeligt vil være mærket af en vis mangel på fortrolighed med det samlede tankeunivers og påfører min samlæsning den metodiske svaghed, at mit udvalg af Grundtvigtekster uvægerligt vil være præget af en vis mangel på overblik over det samlede forfatterskab. Den skævhed og svaghed prøver jeg at råde bod på ved så agtpågivende som muligt aldrig at udlede for nagelfaste tolkninger af de udtryk, jeg vælger ud af Grundtvigs termi- 
nologi, og ved altid så omfattende som muligt at citere de tekster, jeg lægger til grund for min udlægning af Grundtvigs menneskesyn. I øvrigt må jeg tilstå, at beskæftigelsen med Grundtvig ud fra Irenæus har åbnet mine øjne for mere lyse sider i Kierkegaards antropologi, som jeg hidtil ikke har haft blik for, hvilket utvivlsomt er smittet af på mine tekstanalyser.

\section{Irenous}

Grundtvig og Kierkegaard har på hver sin måde stiftet bekendtskab med Irenæus, biskop i Lyon i det 2. årh. Grundtvig læste for første gang Irenæus i 1823 og blev så optaget af ham, at han i 1827 oversatte femte og sidste bog af hans apologetiske skrift om den sande kristendom $^{1}$ under titlen "Om Legemets Opstandelse og Deel i Guds Rige". Kierkegaard synes ikke at have studeret Irenæus' egne tekster, men læste godt ti år senere end Grundtvigs oversættelse om Irenæus' teologi i Johannes Adam Möhlers Athanasius der Große und die Kirche seiner Zeit, bd. 1-2, Mainz $1827 .^{3}$

I femte bog af Irenæus' apologetik, især i kap. VI, "Der hører Aand og Sjæl til et, efter Guds Billede og Lignelse, fuldstændigt Menneske", findes der vigtige elementer af hans menneskesyn, som bygger på 1 Mos 1,26: "Gud sagde: 'Lad os skabe mennesket i vort billede, så de ligner os! (...).' " Eller som det lyder i 1740-oversættelsen af Det Gamle Testamente: "Og Gud sagde: lader os giøre et Menneske i vort Billede, efter vor Lignelse (...)." Det er begrebsparret 'billede' (på latin 'imago') og 'lignelse' eller 'lighed' (på latin 'similitudo'), der er afgørende i denne sammenhæng. Herom heddet det $\mathrm{i}$ indledningen til kap. VI i Grundtvigs fordanskning: "ved Faderens Hoender, det er: ved Sønnen og Aanden, kommer Mennesket, og ei blot et Stykke af Mennesket, til at ligne Gud, og Sjoel og Aand kan være en Deel af Mennesket, men aldrig hele Mennesket, thi et fuldkomment Menneske er en Sammensmeltning og Forening af Sjalen med Faderens Aand, og med Konst-Værket af Kiød efter Guds Lignelse." " Det bør bemærkes, at Irenæus' hovedanliggende her i femte bog er at argumentere for legemets eller kødets opstandelse, hvorfor det er vigtigt for ham at understrege det fuldkomne, dvs. det åndelige menneskes kødelighed eller legemlighed. Derfor hedder det videre:

naar man regner Kiød-Stoffet og Konst-Værket fra, og tænker sig blot Aand, da har man ikke længere et aandeligt Menneske, som svarer til sit Navn, men enten Menneske-Aanden, eller Guds Aand. Naar derimod denne Aand, forenet med Sjaclen, forbindes med Legemet, da skabes det aandelige og fuldkomne Menneske, som er Skabningen efter Guds Billede og Lignelse. ${ }^{5}$ Hvis derimod Sjeelen mangler 
Aanden, da er Mennesket blot besjeelet, og kiødelig, og er da ufuldstæendig, da han vel bærer Lignelsen i Konst-Værket, men har ikke Ligheden som Aanden giver, men han er ogsaa ufuldstændig, naar man tager Lignelsen bort, og forskyder Konst-Værket, thi da tænker man ikke længer paa hele Mennesket, men, som sagt, enten paa en Deel af Mennesket, eller paa noget Andet, udenfor ham. ${ }^{6}$

Det er altså "Sammen-Smeltningen og Forbindelsen af alle disse Dele", dvs. legeme, sjæl og ånd, "som udgiør det fuldstændige Menneske". 7

Grundtvigs oversættelse er ikke så ligetil at forstå, og hans frie, ukonkordante gengivelse af de samme latinske ord med forskellige danske, gør det ikke nemmere. I det følgende skal jeg forsøge at give en tæt parafrase på grundlag af den latinske tekst med skyldig hensyntagen til Grundtvigs forståelse af den og med angivelse af de latinske hovedord i parentes.

Ved Faderens hænder, dvs. ved Sønnen og Ånden, bliver det hele menneske til efter Guds lighed (similitudo). Vel kan sjæl og ånd være en del af mennesket, men aldrig hele mennesket. Det fuldkomne (perfectus) menneske er en sammensmeltning og forening af sjælen med Faderens Ånd, som det modtager, og en sammenføjning med kødet, som er det dannede legeme (plasma) ${ }^{8}$ efter Guds billede (imago). Hvis man stryger selve kødet, ${ }^{9}$ dvs. legemet (plasma), og kun vil tænke på ånden alene, så er der ikke længere tale om et åndeligt menneske, men blot om menneskets ånd eller om Guds Ånd. Når derimod menneskets ånd, sammenblandet med sjælen, forener sig med legemet (plasma), da skabes, i kraft af Åndens udgydelse, ${ }^{10}$ det åndelige og fuldkomne menneske, og dvs. som det blev skabt efter Guds billede (imago) og lighed (similitudo). Hvis sjælen derimod mangler Ånden, så er mennesket kun besjælet og kødeligt og således ufuldkomment (imperfectus); det bærer ganske vist billedet (imago) i legemet (plasma), men har ikke ligheden (similitudo), som modtages gennem Ånden. Modsat er mennesket også ufuldkomment, hvis man stryger billedet (imago) og foragter legemet (plasma), for da er der heller ikke længere tale om et helt, men kun om et delvist menneske. Det er sammenblandingen og enheden af legeme, sjæl og ånd, der udgør det fuldkomne menneske.

Irenæus' anliggende i dette skrift er, som allerede nævnt, at argumentere for kødets opstandelse imod de gnostiske kættere, der betragtede kødet eller legemet som foragteligt og som et fængsel for sjælen og ånden, der anses som det ædle. Derfor er det alt afgørende for ham her at få fremhævet kødet, det dannede legeme (plasma), som en kristen-teologisk set uopgivelig del af det skabte menneske. Han argumenterer bibelsk. Dels er mennesket ifølge 1 Mos 1,26 skabt efter eller i Guds billede (secundum imaginem) og Guds lighed (secundum 
similitudinem). Dels er mennesket ifølge 1 Mos 2,7 dannet af støv fra jorden og som sådan et kødeligt legeme (plasma, et "Konst-Værk"), der har fået Guds Ånd indblæst. Som skabt udgør det altså en ubrydelig enhed af legeme, sjæl og ånd; fjernes én af delene, er det ufuldstændigt eller ufuldkomment. Her er Irenæus af den opfattelse, at Guds billede (imago) bæres i legemet og sjælen, mens Guds lighed, lignelse eller måske bedre lignelighed (similitudo) modtages af Ånden, der forener sig med sjælen og gør mennesket åndeligt.

Dog må det erindres, at Irenæus i kap. VI taler om det fuldkomne og åndelige menneske, det åndeliggjorte og frelste menneske, i hvem legeme, sjæl og ånd på ny er forenet. Han skriver: "Desaarsag forklarer Apostelen sig ogsaa tydeligere om det fuldstændige [perfectus] og aandelige Saligheds-Menneske, i sit første Brev til Thessalonicherne, hvor han siger: men Fredens Gud hellige eder fuldstondig [perfectus], saa hele eders Aand, og Sjcel og Legeme [corpus], upaaklagelig maa blive i Behold, ved vor Herres Jesu Christi Tilkommelse! Eller af hvad Aarsag skulde han vel ønske disse Trende: Sjæl og Legem [corpus] og Aand, fuld og heel Varighed ved Herrens Tilkommelse, dersom han ikke vidste, at de Trende skulde paa Ny forbindes, og have een og samme Salighed tilfælles, hvorfor han og siger, at de er fuldkomne [perfectus], som yde Herren de Trende upaaklagelig! De er altsaa fuldkomne, som baade have Guds Aand blivende i sig, og bevare baade Sjæl og Legem upaaklagelig, faste i Guds Tro, det er den Tro, der skyldes Gud, og omhyggelige for den Retfærdighed, der skyldes Næsten."12

Dette, at de tre, legeme, sjæl og ånd, skal "paa Ny forbindes”, må forudsætte, at de er blevet adskilt. Og det rejser spørgsmålet om, hvad der sker med Guds billede og Guds lighed på grund af syndefaldet, om de begge tabes. I de sammenhænge, hvor dette er Irenæus' anliggende, er han af den opfattelse, at billedet bæres i menneskets sjæl og ligheden i dets ånd. Herom skriver Möhler sammenfattende: “daß Irenäus unterscheidet zwischen Ebenbild (imago) und Aehnlichkeit (similitudo) Gottes. Das Ebenbild Gottes trägt der Mensch, indem er die Seele hat; ähnlich ist er aber Gott, wenn er den heiligen Geist hat und heilig lebt; diese heiligen Menschen nennt Irenäus auch geistige (spirituales), vernünftige (rationales) und vollkommene". ${ }^{13}$ Herefter bringer Möhler følgende citat fra Irenæus:

der vollkommene Mensch besteht aus drei Theilen, aus dem Fleische, der Seele und dem Geiste: der eine befreiet und bildet, und das ist der Geist, der andere wird vereinigt und gebildet, das Fleisch; zwischen inne ist die Seele, welche zuweilen dem Geiste folget und von ihm gehoben wird; zuweilen aber dem Fleische beistimmt, und in irdische Begierde fällt." $" 14$ 
Friheden er her af Irenæus tillagt sjælen, hvilket også fremgår af følgende citat: "Frei schuf Gott den Menschen von Anfang an; er hat seine Selbständigkeit, so wie seine Seele, um den Willen Gottes freithätig zu vollziehen, und nicht gezwungen; denn Gewalt ist nicht bei Gott, wohl aber guter Rath. ${ }^{15}$

Ud fra Möhler kan Irenæus' menneskesyn set i forhold til tabet på grund af syndefaldet og til genoprettelsen eller genfødelsen i kraft af Kristus kort beskrives således: Mennesket består af legeme og sjæl, som er dets substans, der ved at forenes med Guds Ånd bliver et fuldstændigt, åndeligt menneske. Hvad der er tabt i Adam, er genvundet $\mathrm{i}$ Kristus. Men ikke alt er tabt på grund af syndefaldet. Guds billede er stadig i menneskets sjæl, hvorimod Guds lighed, som er i menneskets ånd, er gået tabt og skal genfødes af Helligånden. Guds billede i sjælen er friheden, som mennesket bevarer, og som til tider bifalder kødet og forfalder til jordisk begær, til andre tider udfører Guds vilje og underkaster sig hans Ånd, der på ny skænkes i Kristus. ${ }^{16}$

Da Grundtvig og Kierkegaard, ganske vist på hver sin måde som påvist, har været under indflydelse af Irenæus, skal hans her skitserede menneskesyn danne folie for den følgende fremlæsning og samlæsning af Grundtvigs og Kierkegaards syn på mennesket set i forhold til syndefaldets konsekvens for dets skabelsesgivne gudbilled-lighed.

\section{Grundtvig}

I kap. 11, "Det medfødte og det gienfødte Menneskeliv", i Den christelige Børneloerdom ${ }^{17}$ skriver Grundtvig, at det er "aabenbar selvmodsigende, vrævlevurnt og yderst kiedsommeligt", når visse teologer på den ene side påstår både "Menneskets Skabelse i Guds Billede og Fornyelsen efter det samme Billede ved Troen paa den Guds Søn og Menneskens Søn, Vorherre Jesus Christus", og på den anden side hævder, "at 'Syndefaldet', som er indtruffet mellem Skabelsen og Fornyelsen, og som giør Gienfødelsen og Fornyelsen uundværlige til Salighed, dette Syndefald skal saaledes have vanskabt eller rettere udslettet og i Bund og Grund ødelagt Mennesket og hele Menneske-Livet i Guds Billede, at der er ikke Gran eller Spire tilbage af den medfødte Herlighed og af det medskabte Forhold mellem Gud og Menneske". ${ }^{18}$ Derfor tager han også skarpt afstand fra den grundsætning, at mennesket ved syndefaldet blev "saa fremmed fra Gud og alt Guddommeligt, som om han aldrig havde været skabt i Guds Billede, altsaa blev Mennesket enten et blot Dyr, eller dog et $U$ Menneske". ${ }^{19}$

Heroverfor stiller Grundtvig sit eget synspunkt, at Bibelens åbenbaringshistorie kun kan være sand under den forudsætning: "at Menneske-Livet, før og efter Syndefaldet og før og efter Gienfødelsen, 
er aldeles eensartet og igrunden det selvsamme, thi dersom Adams Menneske-Liv i Guds Billede var tilintetgjort ved Syndefaldet, da hverken kunde Gud tiltale den faldne Adam eller Adam svare ham". ${ }^{20}$ Og de talte jo netop sammen, Gud og Adam, i Edens Have efter syndefaldet, jf. 1 Mos 3,9-12. Grundtvig benægter naturligvis ikke, at der er sket et fald, men han fastholder, at det faldne menneske er "opreist af Faldet, frelst, helbredt og guddommelig udstyret i Christus, og saaledes ved Daaben uafbrudt gienfødt hos den Christne Menighed, saa at Menneske-Livets christelige Gienfødelse og Fornyelse altid og hos os alle forudsætter og udspringer ved den Helligaand af det gamle, oprindelige Menneske-Liv.", 21

Mennesket er altså ikke fuldstændig ødelagt af syndefaldet, og Guds billede er ikke totalt vanartet og tabt på grund af faldet, som i den augustinsk-lutherske tradition fører arvesynden med sig (herom senere). Jeg er selvfølgelig opmærksom på, at Grundtvig her kun taler om Guds billede og ikke om Guds lighed; og dog taler han om "den medfødte Herlighed", der i min tolkning er udtryk for foreningen af Guds billede og Guds lighed. Og denne forening er tabt, netop fordi tvivlen bragte mennesket til fald og "berøvede det Aanden, som er Guds-Ordets Livs-Kraft, og gjorde det til Syndens Slavinde og Dødens Rov". 22 Derfor er det også kun Ånden, Guds Ånd, Helligånden, der i dåben kan genføde og genetablere den skabte forbindelse mellem Guds billede og Guds lighed.

Spørgsmålet er nu: Hvori består den "Gran eller Spire", der er ladt tilbage i mennesket, og hvor findes den? I mit forsøg på et svar vil jeg i første omgang henholde mig til et par salmer eller åndelige sange fra samme tid. ${ }^{23}$ Først "Hvor skal jeg Guds Billed finde?"24 Her spørger Grundtvig videre i første strofe, om mennesket har tabt det Guds billede, som det skabtes i, eller om det "sank i Syndens Spor" med mennesket "i Jord", så det aldrig vendte tilbage med glans. Og han svarer i anden strofe, at "Guds Billed fødtes / Glansfuldt i Marias Søn", hvorved der blev rådet bod for det faldne menneske. Derpå følger det, der er afgørende i vores sammenhæng:

I hans Lys [altså i lyset af Kristus] jeg ser det grandt:

Billedet kun halvt forsvandt,

Og naar Frelsnings-Dagen gryer,

Helt $\mathrm{i}$ os det sig fornyer. ${ }^{25}$

Og videre i slutningen af tredje strofe:

Kan vi høre og forstaa,

Hvad Guds-Ordet lyder paa,

[dvs. hvad Kristus som "Guds Mund af Støv paa Jord" har talt]

Har til det vi Mund og Mæle, 
Er Guds Spejl i vore Sjacle.

Guds billede er altså i menneskets sjæl i form af ordet, det vil her sige i sproget. Det udvikles videre i fjerde strofe:

Ordet om, hvad intet Øje,

Gjort af Kjød og Blod, kan se,

Ordet om den evig høje,

Paa hvis Ord al Ting maa ske,

Dette Ord med Aand og Liv,

Gjenlyd af Guds Almagts-Bliv,

Det Guds Billed er her neden

Og hans Glans i Evigheden.

I den følgende strofe bliver det klart, at Guds ord er kommet til mennesket to gange. Første gang i Guds skaberord - her kaldt hans "Almagts-Bliv" - der resterer som en "Gjenlyd" heraf i det skabte menneske. Genlyd betyder her ikke ekko, men dels efterklang ${ }^{26}$ og genklang af, resonans og klangbund for Guds ord, dels evnen til både at tale og høre og til en vis grad også at forstå Guds ord. Sproget "Mund og Mæle", som det kaldes - er den forblevne rest af Guds billede som et reflekterende spejl i sjælen. Dette sidste kommer ikke blot til udtryk i tredje strofe, men også her i femte strofe:

Var Guds Billed ej deri,

Blinde var for Gud da vi;

I Livs-Ordet [Guds ord, evangeliet], som ej fejler,

Lysets Gud hos os sig spejler.

Anden gang, Gud kommer til mennesket, er i Guds Søn som "SyndsForlader", hvor der ved Helligånden sker en heling af Guds billede, så det atter bliver helt og mennesket kommer til at ligne Gud (jf. Irenæus). Det sidste udtrykkes i syvende og sidste strofe:

Saa dit Billed du velsigne

Med din Aand $i$ Jesu Navn,

At som Børn vi dig maa ligne,

Samles i din Fader-Favn

Til at see med Øine ny,

Hvad end skjuler sig bag Sky;

Klarhed over Livets Kilde,

Aasyn dit, det evig milde!

Mens Grundtvig i fjerde strofe sagde, at intet øje, som er gjort "af Kjød og Blod", kan se Guds skaberord, så siger han nu her i sidste strofe, at mennesket skal "see med Øine ny", efter at det ved Helligånden igen er kommet til at ligne Gud. Det rejser spørgsmålet: Hvorfor 'ny', hvis det ikke har været ødelagt? Der er to mulige svar. Enten gør Grundtvig sig skyldig i en uklarhed, eller også udtrykker 
han bevidst en dialektisk spænding mellem to synsmåder afhængig af synsretningen: skabelsesteologisk set er øjet ikke ødelagt, men kristologisk set er det fornyet. Men det rejser et nyt spørgsmål: Hvordan fremstår denne fornyelse? Ud fra forestillingen om altings skabelse af intet ('creatio ex nihilo') var det i den lutherske ortodoksi en udbredt teologisk opfattelse, at ligesom Gud i begyndelsen skabte alt af intet, således bliver også det faldne, ødelagte og derfor tilintetgjorte menneske skabt af intet i Kristus, så der er tale om både en første og en anden 'creatio ex nihilo'. Hvis det er den opfattelse, Grundtvig her bringer til udtryk, kommer han til at slå sig selv for munden. Men en anden og mere sandsynlig tolkning ligger da også for, den nemlig, at fornyelsen ikke er en nyskabelse, men en genoprettelse, en genfødelse i Kristus ved Helligånden (i dåben) - jf. anden strofe: "Billedet kun halvt forsvandt, / Og naar Frelsnings-Dagen gryer, / Helt i os det sig fornyer." Her er forstavelsen gen afgørende; ligesom noget ikke kan gentages, hvis det ikke allerede er noget, kan gudbilledet heller ikke genoprettes, hvis det er ødelagt i en sådan grad, at det er blevet til intet. Altså handler det ikke om en nyskabelse af intet, men om en genheling af det halvt bevarede, en genfødelse ved syndernes forladelse i dåben, så øjet gjort "af Kjød og Blod" genfødes som troens øje, der kan se det gamle på en ny måde, se med klarhed. Om gudligheden derimod nyskabes, må indtil videre stå hen som et uløst problem; men muligt er det.

Den samme opfattelse af Guds billede som en bevaret genlyd af Guds skaberord, altså som et 'genlydsord', i det skabte menneskes sjæl kommer til udtryk i salmen "I Begyndelsen var Ordet, / Var guddommeligt hos Gud". ${ }^{27}$ Her hedder det i anden strofe:

I Begyndelsen var Ordet,

Gjenlyds-Ordet i vort Bryst,

Ej begravet, men dog jordet,

Himmelfødt med jordisk Røst,

Mægtede kun alt at nævne,

Havde ingen Skaber-Evne,

Kunde dog med ydmyg Bøn

Hos Guds-Ordet, hos Guds Søn,

Lys og Liv sig laane.

Jeg parafraserer. Genlyden af Guds skaberord er bevaret i menneskets bryst, dvs. i hjertet eller i sjælen, som 'genlydsordet' fra skabelsens begyndelse. Det har sin oprindelse i den himmelske Guds skaberord ("Himmelfødt"), og vel er det "jordet", så sandt som mennesket er dannet af jord (jf. 1 Mos 2,7), men det er ikke derved gået under ("Ej begravet", hvilket er afgørende i denne sammenhæng), det er bibeholdt 
som en "jordisk Røst". Ganske vist besidder det i sproget evnen til at "nævne", gensige alt, men det er begrænset, det fattes evnen til at skabe (den evne er forbeholdt Gud), dog ikke mere begrænset, end at det med sine ord kan udtrykke sig i bøn og derved låne lys og liv hos "Guds-Ordet, hos Guds Søn" (jf. Joh 1,1-4). Hvad der skete med genlydsordet efter skabelsen, udreder Grundtvig i strofe tre:

I Vildfarelse afskares

Gjenlyds-Ordet fra sin Rod, Ytred kun, hvad aabenbares

Kan igjennem Kjød og Blod,

Blev en Bold for alle Vinde,

Hvor ej til et dunkelt Minde

Om Guds Røst i Paradis

Med et Suk paa Kvinde-Vis

Fattig det sig fæsted.

Jeg parafraserer igen. I syndefaldet blev 'genlydsordet' afskåret fra sin guddommelige oprindelse, fra Guds Ånd, så det indtil videre kun kan udtrykke det, der kan åbenbares gennem det skabte, det naturlige menneske. Og det ville blive som en bold, der af vindpust førtes snart i én, snart $i$ en anden retning, hvis ikke det med "et Suk", den mindst tænkelige af følelserne ("paa Kvinde-Vis") fremkaldte artikulation af sprogevnen, fattigt fæstede sig til "et dunkelt Minde" om "Guds Røst i Paradis". Altså: Mennesket er blevet afskåret fra Guds Ånd og har således tabt Guds lighed på grund af syndefaldet, men det har på trods af faldet bevaret Guds billede i sjælen i form af genlydsordet, evnen til at høre og tale, og i form af et dunkelt minde om Guds røst - og, skal vi se om lidt, også i form af en trang i hjertet. ${ }^{28}$

De resterende strofer i denne salme vil senere blive gennemgået. Her vil jeg som et pietistisk modstykke til Grundtvig kort inddrage to salmer af H. A. Brorson. Først "Min Jesu! Grund til al vor Lyst". ${ }^{29}$ første strofe spørger digteren Jesus, hvad det bitre er, der gør ham beklemt i brystet og giver ham stød og sting i hjertet, så han må sukke dybt. Hertil lyder svaret $i$ tredje og fjerde strofe:

Du seer, Guds Billede er skjændt,

Som var i Sjælen inde,

Og hvordan Mørkhed har bespændt

De arme Folkes Sinde,

Hvor Hellighedens Brudekrands

Af Sjæl og Hjerte, Sind og Sands

Er ganske tabt og borte.

Du seer, hvorledes vi har mist'

Vor Friheds Lyst og Ære,

Og fik igjen ved Satans List 
Det Syndens Aag at bære,

Det Mesterstykke af Guds Haand,

Vor Tunge seer Du nu i Baand,

Af Satan selv belænket.

Her genfindes flere af de netop omhandlede elementer. Guds billede, som oprindelig sad i det skabte menneskes sjæl, er i den grad skændet og ødelagt, så mørke har omspændt erindringen, og hellighedens forening af sjæl og hjerte, sind og sans, altså Guds lighed, er tabt og forsvundet. Friheden er mistet i synden, og tungen, den skabte evne til at tale, er bundet og lænket af Satan. Altså er ikke blot Guds lighed gået tabt, men der er heller ikke levnet den mindste rest af Guds billede, så lidt som der er efterladt den ringeste mulighed for at kunne tale til eller om Gud. Synden har totalt ødelagt det skabte menneske. Dog kan det bede til Gud om, at han vil høre sin Søns sukke, åbne sit hjerte og med sin "fuldkomne Naade-Kuur" gøre sin skabning sund igen (syvende strofe), hvorefter det kan appellere til Jesus og bede (ottende strofe):

O Frelser! lad dit Hephata

Min Mund og Hjerte røre,

Saa skal Du et Halleluja

Af begge Dele høre.

Dette sigter selvfølgelig til beretningen i Mark 7,31-37 om Jesu helbredelse af den stumme og døve mand, hvor Jesus stak en finger i mandens ører, spyttede og rørte ved hans tunge, sukkede og sagde: Effata, luk dig op! Her i salmen betyder det, at mennesket først er i stand til at tale, kristeligt set, når Jesus med sit 'effata' har overvundet syndens stumhed.

Tabet af Guds billede eller i det mindste af rodforbindelsen til Guds billede og dermed tabet af enhver mulighed for at kunne opfylde den ærefulde opgave som et godt træ at bære gode frugter - på grund af det vildførende og alt ødelæggende syndefald - kommer klart til udtryk i Brorsons julesalme "Den yndigste Rose er funden", ${ }^{30} \mathrm{i}$ anden strofe:

Alt siden vi tabte den Ære,

Guds Billedes Frugter at bære,

Var Verden forvildet og øde,

Vi Alle i Synden bortdøde.

Mens tanken om genlyd af Guds skaberord er udelukket hos Brorson, findes den én gang hos Kierkegaard, og det formentlig under inspiration af Grundtvig, i en optegnelse, dateret den 30. aug. 1839, i journalen EE. Grundtvig var blevet ansat som præst ved Vartov 
Hospitalskirke den 28. maj og prædikede første gang den 9. juni 1839 og mange gange efter. ${ }^{31}$ Anledningen er den allerede omtalte beretning om Jesu helbredelse af den stumme og døve mand, ${ }^{32}$ som foranlediger Kierkegaard til at skrive:

Det er Beskrivelsen af den msklige [menneskelige] Erkjendelse, som den var før Xstd [kristendommen], der findes Mc. 7, 31-37. 'han kunde ikke høre' thi Himlen var ikke aabnet for ham, og Guds Ord havde ikke gjenlydt (thi skabt var vel Alt af Gud, men Gjenlyden, Resonantsen i Skabningen var der ikke endnu) 'og kunde kun besværlig tale'; thi da det han havde at sige, var Noget han selv havde udfundet, var det ikke stort bevendt. Og saa stor var Forvildelsen i Verden, at det ikke var nok som fordum at sige: det vorde Lys; men Xstus 'sukkede' og sagde ephphata, og saadan er den christelige Veltalenhed, at den maa prise Gud om det end forbødes ('Xstus bød dem, at de Ingen skulde sige det til etc' $).{ }^{33}$

Kierkegaard er her af den opfattelse, at genlyden, dvs. resonansen af Guds ord i mennesket, skønt skabt af Gud, først er mulig, når Guds skaberord genlyder i Kristi ord ved hans indgribende helbredelse. I de forud refererede to salmer har Grundtvig derimod udtrykt den forståelse, at 'genlydsordet' er bevaret som en efterklang af Guds skaberord, der kan vinde genklang i ethvert skabt menneske. Men - spørgsmålet er, om der dybest set er et 'derimod'. For mens Grundtvig i disse salmer taler om den almene evne hos det skabte menneske til at høre Guds ord, så handler det i Kierkegaards optegnelse om manglen på den specifikke evne hos det naturlige menneske, dvs. forud for og uden Kristus, til at høre Kristi ord, altså til at høre evangeliet. En tilsvarende tilgang gør sig gældende i den prædiken, Grundtvig holdt i Vartov på 12. søndag efter trinitatis. Her drejer det sig nemlig som hos Kierkegaard ikke om evnen til at høre Guds røst, men om muligheden for at kunne høre Guds Søns røst.

Inden jeg går videre, skal jeg nævne, at der i journalen EE er andre indicier på, at Kierkegaard $\mathrm{i}$ den periode hørte Grundtvig prædike $\mathrm{i}$ Vartov. Så selv om ordet 'genlyd' ikke forekommer i Grundtvigs bevarede manuskript, der i kraft af sin korthed kun kan have tjent som udkast og baggrund for den holdte prædiken, ${ }^{34}$ tyder dens spor i Kierkegaards tekst på, at Grundtvig faktisk har talt om det; men det må forblive en gisning.

I den indledende bøn i prædikenudkastet hedder det: "Himmelske Fader! læg Du med din Aand din Finger i vort Øre, saa vi høre din Søns Røst og rør ved vor Tunge, saa vi tale ret, tale indtrængende høit og klart om din Salighed!" Til en begyndelse prædiker Grundtvig ganske vist om det vidunderlige ord, som Gud ved skabelsen har lagt på menneskets læber, så det er i stand til at tale med Gud som en mand med sin næste. Og dog er de utallige, som godt nok har åbne ører for al 
verdslig tummel og tale, men døve ører for "Guds Ord", og som godt nok har mund og mæle til at ophøje sig selv, men er stumme til at udsige "sin Skabers og Gienløsers Priis". Disse åndeligt døvstumme er dybt at beklage, både på grund af deres store antal og på grund af det fortvivlede i deres tilstand, at skønt de har ører, hører de ikke, og skønt de har mund, taler de kun på en måde, så de fortørner Gud og vanærer deres herkomst. Og Grundtvig tænker sig tilbage til den tid, hvor præsterne ved dåben lagde deres finger i ørerne på spædbørnene og rørte ved deres tunge og sagde: "Ephata, det er luk dig op!" For måske det kunne forhindre, at man midt i kristenheden skulle støde på skarevis af mennesker, der ikke har øre for Kristi navn, "hvormed de i Daaben er kaldte", og ikke har tunge til at "bekiende Herren til Gud Faders Ære".

Efter at have omtalt Herrens (Jesu) forbud mod at kundgøre hans velgerning mod den døvstumme, vender Grundtvig tilbage til temaet med den tusindtallige skare af åndeligt døve og målløse, men nu til den dobbelte velgerning, at Herren ved "ved sin Faders Aand" dels har åbnet deres ører og hjerte til at høre "Guds Naades Ord", dels har helbredt dem til at "føre det evige Livs Ord". Altså har Herren forbarmet sig og gør "de Døve hørende og de Maalløse talende!" Denne Herrens velgerning over for hans "hardtad døvstumme Menighed" (altså over for de døbte), skal til, for at deres ører kan åbnes til at høre "hans Røst" og deres tungebånd kan løsnes til klart og højt at forkynde "Navnet over alle Navne", i det navn, hvori det er givet alle mennesker "at helbredes, at knæle og opreises". ${ }^{35}$ Prædikenmanuskriptet ender uafsluttet med, at alle troende slægter, som har bekendt og følt "Herrens Nærværelse iblandt Sine", "giættede alle derpaa, at Hemmeligheden laae i 'Guds Ord,' dette Sønnens dybe”.

Hvad Grundtvig videre har sagt, kan vi kun gætte på, og det skal vi ikke. Men temaet i udkastet er klart nok. Og det udtrykker, at mennesket, skønt døbt, er døv og stum for Guds Søns røst, indtil han, "saaledes som Han har gjort og daglig giør", åbner vore ører, så "vi høre klarlig Herrens Røst", og løser vores tunge, så "vi til Hans Priis kan udsige og udsjunge hvad der var skjult for mange Slægter", og hvordan "vi kan være og leve og røres i Ham, ${ }^{36}$ naar Ordet er os nær i vor Mund og i vort Hjerte, ${ }^{37}$ det Troens Ord, vi forkynde."

Tungen har altså som hos Brorson været bundet. Spørgsmålet er dog, om der ikke hos Grundtvig er tale om en dialektik, som ikke findes hos Brorson, en spænding mellem et skabelsesteologisk og et hamartiologisk eller kristologisk perspektiv. Skabelsesteologisk kan mennesket gentage Guds ord, men hamartiologisk kan det ikke forkynde evangeliet, bekende Kristus og lovprise, hvad der var skjult, men nu inkarnatorisk set åbenbaret. Dog bemærkes det, at der også i 
det kristologiske perspektiv er tale om menneskets mulighed for "at helbredes, at knæle og opreises", altså ikke om at nyskabes, men om at helbredes, så det halve gøres helt, ikke om at være faldet, men om selv at knæle i erkendelse af at være faldet fra forholdet til Guds Ånd, og i bøn om at blive genforenet med hans Ånd, i kraft af, at Gud ved Ånden lægger sin finger i vore ører og rører ved vores tunge, så vi som oprejste ved Kristus făr evnen til dels at høre hans røst, dels at udtale hans budskab. I så fald er Guds billede om end ikke fuldt intakt, så dog halvt i behold i sjælen, så vi kan knæle og bede og gensvare på Kristi ord. Dog er den mulighed også til stede, at rækkefølgen - "at helbredes, at knæle og opreises" - skal tages så bogstaveligt, at mennesket først kan knæle og bede, når det er helbredt, så det efter bønnen oprejses. Jeg tør ikke afgøre det, og slet ikke på baggrund af et (løst) prædikenudkast, hvis udfoldelse vi ikke kender.

I øvrigt skal jeg ikke her videre forfølge spørgsmålet om, hvordan den tanke, at Guds billede delvis bevaret i sjælen som genlydsordet af hans skaberord med evnen til at høre og til at eftersige Guds ord, skal forstås $\mathrm{i}$ forhold til døvheden og stumheden over for Sønnens røst og ord. Dog skal det bemærkes, at en parallel tankegang, med visse modifikationer, findes i salmen "Op til Guds Hus vi gaa" fra $1856 .{ }^{38}$ Her hedder det i strofe tre:

Vor Sjæl er døv og stum

For Evangelium,

Men høres vil Guds Ord

Og føres trindt paa Jord.

Altså er sjælen, sædet for Guds billede og genlydsordet, både døv og stum for evangeliet, for Guds Søns røst og ord. Men "Guds Ord”, som her må stå for hans Søn, siger til sjælen (i strofe fire): "Luk op!” og spørger, om den vil frasige sig løgnen og nu, her i Guds hus ved gudstjenesten, tro på Guds sandhed. For (strofe fem):

Det er hans Effata,

Og Tungen svarer ja!

Guds Røst, som Almagts Haand,

Os skar for Tungebaand.

Sjælen er med andre ord ikke helt stum, men kan, fordi Guds røst ved skabelsen almægtigt forud har beredt mennesket efterklangens høreog taleevne, dels bede Gud om at lukke sjælen op (jf. første strofe), dels med øret opfatte og med tungen bekræftende reagere på Guds Søns røst, når han siger: "Effata".

Hvorvidt "Op til Guds Hus vi gaa" som i den nye udgave af Den Danske Salmebog skal forstås som en dåbssalme (vel pga. anden strofe, "I Daab med Aand og Vand / Her staar vor Frelsermand"), skal 
ikke her diskuteres. I Salmer og aandelige Sange er den anfort som en evangeliesalme til 12. søndag efter trinitatis.

\section{Syndefald og arvesynd}

Kierkegaard var fra sin tidligste ungdom optaget af tanken om arvesynden som en følge af syndefaldet, først og fremmest fordi den beklikker friheden; for uden frihed, hævder han, opstår synden $i$ kraft af arvesynden og videreføres med nødvendighed $\mathrm{i}$ arvesynden og bliver derfor ikke menneskets egen skyld. Inden jeg går nærmere ind på Kierkegaards argumentation imod den traditionelle forståelse af arvesynd og omtolkning af den til et eksistensvilkår, vil jeg kaste et kort blik tilbage i dogmehistorien.

Forestillingen om arvesynd, dvs. at synden forplantes gennem den seksuelle akt og dermed arves, efter at den ved Adams syndefald er kommet ind $\mathrm{i}$ verden, bygges $\mathrm{i}$ den dogmehistoriske tradition på flere steder i Bibelen. Først og fremmest på syndefaldsberetningen i 1 Mos 3. Dernæst på S1 51,7: "See, jeg er født i Misgierning, og min Moder haver undfanget mig i Synd", som det hedder i 1740-oversættelsen af Det Gamle Testamente. Og videre på Rom 5,12-14:

Altsaa, ligesom Synden kom ind i Verden ved eet Menneske, og Døden ved Synden, og saaledes Døden trængte igiennem til alle Mennesker, i det de syndede alle; thi Synden var i Verden indtil Loven; men hvor der ikke er Lov, tilregnes ikke Synd. Dog herskede Døden fra Adam til Moses, ogsaa over dem, som ikke syndede i Liighed med Adams Overtrædelse, hvilken er et Billede paa ham, som skulde komme

som stedet lyder i 1819-oversættelsen af Det Nye Testamente.

Med Augustin (354-430) blev forestillingen om arvesynd gjort til et dogme, der fastslår, at synden er virksom i kønsakten og derved $\mathrm{i}$ ethvert menneskes tilblivelse, og at ethvert menneske, fordi det er født i og med synd, har mistet evnen til at gøre det gode. Da mennesket af synden fastholdes $i$ et afmægtigt slaveri, kan det ikke selv medvirke til sin frelse; den afhænger fuldstændig af Guds forløsende og uforskyldte nåde. Denne nåde opfattede Augustin som en indgydelse af den guddommelige kærlighed, der dels forvandler menneskets timelige begær til kærlighed til Gud, dels nyskaber menneskets vilje til at følge Guds vilje.

Jeg har med velberåd hu brugt vendingen 'forestillingen om arvesynd', for i den tidlige kirkelige tradition benyttes normalt det latinske udtryk 'peccatum originale', 'den oprindelige synd', overtaget 
på engelsk som 'original sin', og i den lutherske tradition på tysk gengivet med 'Erbsünde'.

Hvad angår uoverensstemmelsen mellem Augustin og Pelagius (o. 400), tillader jeg mig at citere fra Kierkegaards referat af $\mathrm{H}$. N. Clausens dogmatiske forelæsninger i vintersemestret 1833-34 og sommersemestret 1834, da netop friheden her spiller en afgørende rolle. Ifølge referatet af $\S 38$ siger Clausen: "Idet Pelagius ikke alene nægtede en Forplantelse af Synden; men overhovedet enhver moralsk Indflydelse fra Adams Synd paa den msklige [menneskelige] Natur, ikke alene forfægtede den moralske Frihed; men paastod, at Msk. [mennesket] fødes ligesaa reent og ufordærvet som det oprindelig er skabt, blev han ved eensidig Iver for den personlige Frihed bragt til at miskjende saavel Individets Forhold til Slægtens Liv, som Msk.[s] Forhold til Gud. Imod ham og hans Tilhængere satte Augustinus den Lære: at alle Msk.[er] havde syndet i og med Adam, og have modtaget som retfærdig Straf en ved Fødselen fordærvet Natur, som alene har Frihed til at giøre det Onde." ${ }^{, 39}$ - Om Guds billede siger Clausen i referatet af $\S 23$ : "Mennesket er skabt i Guds Billede og denne høiere ufortabelige Adel er at søge i Sjalen, som modsættes det forkrænkelige Legeme og navnlig i Sjelens Evner til Tænkning og Selvbestemmelse." 0 Og om forståelsen af Guds lighed i Det Nye Testamente siger han i samme paragraf: "Ved $\pi v \varepsilon v \mu \alpha$ [ånd] forstaaes de høiere aandelige Anlæg, ved hvilke Msk:[et] hæver sig til Lighed med Gud". ${ }^{41}$

Dogmet om arvesynd blev videreført af de lutherske reformatorer og kommer til udtryk i Confessio Augustana, i artikel 2:

Iligemaade lære de [reformatorerne], at efter Adams Fald alle Mennesker, som naturlig fødes, undfanges og fødes i Synden; det er: at de alle fra Moders Liv af ere fulde af ond Lyst og Tilbøielighed, og kunne ikke af Naturen have nogen sand Gudsfrygt eller nogen sand Troe til Gud, og at denne medfødte Syge eller oprindelige Brøst er i Sandhed Synd, hvilken fordømmer og paafører ogsaa nu den evige Død saa mange, som ikke formedelst Daaben ved den Hellige Aand vorde gjenfødte.

I anden halvdel af artiklen accentueres det dogmatiske problem om arvesynden:

De [reformatorerne] fordømme Pelagianerne og andre, som nægte, at denne oprindelige Brøst er Synd, og for at forkrænke Christi Værdskylds og Velgjerningers Ære, paastaae, at Mennesket ved sin Fornufts egne Kræfter kan vorde retfærdiggjort for Gud."42

I De schmalkaldiske Artikler, forfattet af Luther på tysk i 1536, hedder det i 2. del, artikel 4, i afsnittet om synden: “Arvesynden er en så $d y b$ og hoeslig fordoervelse af naturen, at den ikke kan indses af noget 
menneskes fornuft, men må erkendes og tros ud fra Skriftens åbenbaring". ${ }^{43}$ Den kontroversielle lutherske teolog Matthias Flacius (1520-75) fremsatte tilmed den påstand, at arvesynden var blevet menneskets substans i stedet for Guds billede. Omend Konkordieformlen, affattet på tysk kort efter Luthers død i 1546, kan tale om, at arvesynden i stedet for Guds billede er en $d y b$, ond, hoeslig, bundløs, uudgrundelig og uudsigelig fordcervelse af menneskets natur, ${ }^{44}$ så forkaster den dog tanken om, at arvesynden er en substans, dvs. en væsensbestanddel eller egenskab, og fastslår, at den er en accidens, dvs. noget tilkommet. ${ }^{45}$

Disse citater fra de lutherske bekendelsesskrifter er bragt, fordi Kierkegaard alias den pseudonyme forfatter Vigilius Haufniensis anfører dem og en del andre på latin og foretager et frontalt opgør med dem i Begrebet Angest (1844). Det sker i kapitel 1, $\S 1$, "Historiske Antydninger med Hensyn til Begrebet 'Arvesynd", 46

\section{Kierkegaard}

Dogmehistorisk gælder det, at Adams synd ved syndefaldet er den første synd, at ved den kom synden og dermed syndigheden ind $\mathrm{i}$ verden, og at alle andres synd forudsætter denne syndighed, som forplantes og nedarves gennem menneskeslægten. Mens Grundtvig synes at fastholde denne augustinsk-lutherske forståelse af arvesynd, al den stund han kan tale om den som en smitte, der forplantes ved seksuel omgang, ${ }^{47}$ og som en syndighed, der nedarves, ${ }^{48}$ så forkaster Kierkegaard/Vigilius Haufniensis en sådan forståelse og sætter i stedet for arvesynd den første synd ('peccatum originale') og påstår, at ethvert menneskes synd er den første synd, i den forstand, at ved den kommer synden ind i verden for den enkelte.

Synden er en kvalitet, der opstår ved et 'spring', ved det enkelte menneskes, eller rettere ved ethvert enkelt menneskes kvalitative spring; og dette 'spring', som er den enkeltes syndefald, sker i frihedens mulighed og ikke af nødvendighed. Syndigheden derimod er en kvantitet, en ophobning af synd, som vel kan disponere den enkelte til synd, men aldrig være årsag til synd. Enhver er altså selv skyld i den første synd og dermed i synden, som derefter fremtræder i de aktuelle synder eller gerningssynderne og bliver til syndighed. Hermed er menneskets frihed fastholdt og accentueret.

Spørgsmålet er nu, hvad der sker med denne frihed - som efter min tolkning har sæde i sjælen - når synden kommer ind i verden i det enkelte menneskes liv. Og svaret er, at den ikke udslettes, men at den fortaber sig i skylden. For at forklare, hvordan det går til, indfører Vigilius Haufniensis begrebet angst, som er dobbelttydigt: På den ene 
side griber angsten individet og ængster det; på den anden side gribes individet af angsten og ængstes. Denne dobbelttydighed og dobbeltrettethed kommer klart til udtryk i følgende centrale udtalelse:

\begin{abstract}
Angest kan man sammenligne med Svimmelhed. Den, hvis Øie kommer til at skue ned i et svælgende Dyb, han bliver svimmel. Men hvad er Grunden, det er ligesaa meget hans Øie som Afgrunden; thi hvis han ikke havde stirret ned. Saaledes er Angest den Frihedens Svimlen, der opkommer, idet Aanden vil sætte Synthesen, og Friheden nu skuer ned i sin egen Mulighed, og da griber Endeligheden at holde sig ved. I denne Svimlen segner Friheden. (...) I samme Øieblik er Alt forandret, og idet Friheden igjen reiser sig op, seer den, at den er skyldig. Imellem disse tvende Øieblikke ligger Springet, som ingen Videnskab har forklaret eller kan forklare. ${ }^{49}$
\end{abstract}

Den syntese, som ånden vil sætte, er sammensætningen af legeme og sjæl. Men, siger Vigilius Haufniensis, en syntese er utænkelig, hvis ikke de to dele forenes i et tredje. Og dette tredje er ånden, menneskets ånd, som vil konstituere forholdet mellem legeme og sjæl. ${ }^{50}$ Altså har Kierkegaard samme antropologiske opfattelse af mennesket som Irenæus og Grundtvig, at det består af treklangen: legeme, sjæl og ånd. Og pointen er her - som hos Irenæus - at friheden har sæde i sjælen og ikke i ånden. Det bygger jeg på, at friheden så at sige vækkes af ånden, idet den vil sætte syntesen af legeme og sjæl; men da svimler det for friheden, fordi den ser ned i sin egen mulighed for at blive et selv, som forholder sig, og som har ansvaret for, hvordan den forholder sig. ${ }^{51} \mathrm{Og}$ da tager den fejl; den griber endeligheden i stedet for uendeligheden at holde sig ved. Det er dens skyld.

Vigilius Haufniensis' brug af metaforen med dybet og øjet, der skuer ned i det, er af betydning for at fă understreget angstens dobbelttydighed. For hvad fremkalder angsten, dybet eller øjet? Det kan i sin tvetydighed ikke besvares. Angsten er en mellembestemmelse mellem frihed og nødvendighed, den "er ikke en Bestemmelse af Nødvendigheden, men heller ei af Friheden, den er en hildet Frihed, hvor Friheden ikke er fri i sig selv, men hildet, ikke i Nødvendighed, men i sig selv" ${ }^{52}$ Angsten er en fremmed magt, som griber mennesket, men mennesket på sin side lader sig gribe af den - og griber forkert. Mennesket er altså også skyldigt i det. Og bliver skyldigt. Pointen med angstens dobbelttydighed er, at den første synds indtræden i det enkelte menneske, når det frit griber fejl, hverken sker med nødvendighed eller som en tilfældighed. Skete det med nødvendighed, var friheden ophævet; og synden var ikke menneskets egen skyld. Skete det som en tilfældighed, kunne man tænke sig et menneske, der ikke syndede; og det er kristeligt set en umulighed. 
At det er mennesket selv, der er årsag til faldet, fremgår af en optegnelse fra december 1846 i journalen NB. Ud fra en fri gengivelse af Jesu ord: "Frygter ikke for dem, som kun kunne slaae Legemet ihjel", 53 skriver Kierkegaard:

Sandseligt gjælder det nemlig, at et Msk. [menneske] kan falde for en Andens Haand; aandeligt gjælder det, at et Msk. kun kan falde for sin egen Haand - Ingen kan fordærve ham uden han selv. / [D]et Onde fordærver ikke Sjælen i den Forstand som Sygdom Legemet, hvilket tilsidst hører op, døer af Sygdommen. Men Sjælen bliver ved at være. $^{54}$

Åndeligt set er det altså mennesket selv, der fordærver sjælen; men skønt den fordærves, ødelægges den ikke helt, den hører ikke op, udslettes ikke. Dog er den syg, og denne sygdom viser sig symptomatisk i form af sygelig svimmelhed, der har meget tilfælles med den fortvivlelse at fortvivle over sig selv. "Svimmelhed er," hedder det i en kladde fra 1848 til Sygdommen til Døden, "under Bestemmelsen Sjel hvad F.[ortvivlelse] er under Bestemmelsen Aand." 55 Som svimmelheden, den manglende evne til at kunne fokusere på ét, skyldes, at sjælen har mistet friheden til at ville ét, nemlig det gode eller Guds vilje, skyldes fortvivlelsen, at mennesket har afskåret sin forbindelse til Gud som skaber, hvorved dets ånd er blevet adskilt fra Guds Ånd.

Allerede i anden del af Enten - Eller er det beskrevet, hvad der sker, når det umiddelbare menneske fortvivlet vil forblive $\mathrm{i}$ sin umiddelbarhed som et tilfældigt individ og ikke vil gribe sig selv som ånd, ikke blive det selv, det er skabt til at være, ikke vil "blive sig bevidst" og vælge sig selv "i sin evige Gyldighed". "Så indtræder tungsind som et legemlig-sjæleligt symptom på "Aandens Hysteri", dvs. på en lammelse i ånden, hvilket medfører, at mennesket ikke kommer ud af sin adspredthed, så det kan ville ét. Dette tungsind er ikke blot en sygdom i sjælen, det er synd, "er egentlig en Synd instar omnium, thi det er den Synd, ikke at ville dybt og inderligt, og dette er en Moder til alle Synder". Da der er tale om ikke at ville, hænger det sammen med krakeleringen og spaltningen af den skabte frihed - i min optik med det af synden sårede eller syge gudbillede i sjælen. Og selv om mennesket skulle foretage den bevægelse ved ånden "at samle sig" ud af sin adspredthed "og forklare sig i sig selv" som den, det er, så bliver der dog altid lidt tungsind tilbage, "men det hænger sammen med noget langt dybere, med Arvesynden, og ligger i, at intet Menneske kan blive sig selv gjennemsigtigt". Selv om dette er skrevet før opgøret med den traditionelle forståelse af begrebet arvesynd i $B e$ grebet Angest, står det heller ikke her i betydningen nedarvet synd, men som udtryk for ethvert menneskes syndefald, hvorved det falder 
ud af forholdet til Gud som skaber. Eller udtrykt i mine termer: den første synds opståen i og ved det enkelte menneske medfører det totale tab af gudligheden, så forbindelsen mellem menneskets ånd og Guds Ånd er kappet over ved roden eller i grunden. Det er årsagen til, at det ikke kan gøre sig selv gennemsigtig, så det kan se, at det grunder i Gud som skabt af ham. Jeg sagde, at tungsindet sidder i sjælen; det synes at modsiges af, at teksten her lader det ligge i ånden, altså i menneskets ånd. Men det er kun en tilsyneladende modsigelse, for det ligger $\mathrm{i}$ ånden $\mathrm{i}$ den forstand, at det er ånden, menneskets ånd, der har mulighed for at hæve tungsindet. Den mulighed er imidlertid gået tabt på grund af syndefaldet. Derfor vil der, hvad mennesket end selv gør, altid forblive "lidt Tungsind" tilbage i sjælen. ${ }^{57}$

I En Leiligheds-Tale, der er tænkt som "Ved Anledningen af et Skriftemaal", første afdeling af Opbyggelige Taler i forskellig Aand fra 1847 , tematiseres og videreudvikles tungsind, "den Synd, ikke at ville dybt og inderligt", som tvesindethed i modsætning til enfoldighed, der vil ét, det gode, Guds vilje, for "Hjertets Reenhed er at ville Eet". ${ }^{8}$

Jeg foretager en foreløbig sammenfatning, hvor jeg tillader mig at drage på en række andre tekster af Kierkegaard uden at henvise til dem og citere dem: Friheden kan opfattes som Guds billede i sjælen, men den såres og spaltes $\mathrm{i}$ skylden og bliver til tungsind og tvesindethed, men også til trang. Eksistentielt set er mennesket totalt syndigt og kan ikke selv se eller vil ikke selv acceptere, at det er i ufriheden og i usandheden og derfor trænger til helbredelse, men ontologisk set er der en subjektiv rest af Guds billede tilbage i mennesket $i$ form af syndsbevidsthed, af trang til og efter Gud, og i denne syndsbevidsthed og trang efter frihedens gentagelse er mennesket åben for at modtage åbenbaringen om syndsforladelsen og dermed genoprettelsen i Kristus, åben og modtagelig for en helbredelse i grunden.

Dette skabelsesteologiske perspektiv kommer, om end på en anden måde, også frem i Lidelsernes Evangelium, tredje afdeling af $O p$ byggelige Taler i forskjellig Aand, hvor det hedder: "Thi der er en Fordring; skjult i al Kjærlighed er der, ikke selvisk, men dybt og evigt grundende [dvs. som er og virker i grunden], indeholdt en Fordring, hvilken er selve Kjærlighedens Væsen." ${ }^{, 5}$ Og i Kjerlighedens Gjerninger ligeledes fra 1847. Her er der tale om, at Gud som skaber har nedlagt kærligheden $\mathrm{i}$ ethvert menneske, og at mennesket derfor har kærligheden i grunden, hvorfra den kan opelskes eller elskes frem, og videre at mennesket har en grundlæggende trang til at elske. ${ }^{60}$

For at nuancere synspunktet går jeg et skridt tilbage i tiden til den lille journal HH fra 1840. Den indledes med en central optegnelse, hvori Kierkegaard skriver, at hans standpunkt for en ny erkendelseslære ikke skal være "Intet er Nyt under Solen" (jf. Præd 1,9), men "Alt er Nyt i Christo" (jf. 2 Kor 5,17). Det første standpunkt "slaaer 
Livet ihjel ved den abstrakte Monotonie". Det andet standpunkt derimod bygger på: "Nyt ikke blot forsaavidt som det er noget andet, men ogsaa som Forholdet af det Fornyede det Foryngede til det Forældede Udlevede", hvilket desuden vil vise, at kristendommen ikke er "som en ny Lap paa et gammelt Klædebon, men som en Foryngelses-Drik". Og Kierkegaard tilføjer, at de følgende to tankebestemmelser er lige nødvendige: "at Xstd. [kristendommen] er det der ikke opgik i noget Msks [menneskes] Tanke, og dog i det det gives Msk.[et] er ham naturligt, at ogsaa Gud her er skabende."

I den følgende optegnelse skriver Kierkegaard om udsagnet 'alt er nyt i Kristus', at det gælder

isærdeleshed om alle de anthropologiske Standpunkter; thi den egl. Viden om Gud (den gudl. Metaphysik, Treenigheden) er uhørt før og altsaa i en anden Forstand ny i Xsto [Kristus]; her seer man fortrinlig Aabenbarings-Begrebets Gyldighed ligeoverfor det reent humane Standpunkt".

Derfor må man adskille de to udtryk: "Alt er nyt som er en æsthetisk Anskuelse" og "Alt er nyt i Xsto som er en dogmatisk, verdenshistorisk speculativ Anskuelse". 62

Skønt Kierkegaard pointerer, at ordet 'nyt' udtrykker et 'polemisk' forhold mellem det fornyede og det forældede, mellem det foryngede og det udlevede, så ligger det i selve ordvalget, at der med fornyelse og foryngelse ikke er tale om, at der sker en nyskabelse, en anden 'creatio ex nihilo', men om, at det skabte, det forældede og udlevede, bliver nyt i og med Kristus.

En tilsvarende tanke, at kun det forældede kan fornys, såfremt dette gamle stadig er til, findes hos Grundtvig i den 71. strofe i 6. del, "Den Nordiske Menighed", af Christenhedens Syvstjerne:

Ingen har Guld-Taarer fældet,

Som ei Glimt af Guldet saae,

Saa Guds-Billedet, forældet,

Maa i Glands dog for os staae,

Om hos os det skal fornyes,

Thi fornyes kan, som flyes,

Kun, hvad gammelt end er iil. $^{63}$

Og dog er der hos Kierkegaard tale om en kvalitativ forskel før og efter Kristus, for ordet 'nyt' udtrykker også, at det nye er noget andet end det gamle. Eller anderledes sagt: human religiøst, skabelsesteologisk, set er der - i lighed med Grundtvig - tale om det samme menneske før og efter Kristus, men kristelig dogmatisk, soteriologisk, set er der - til forskel fra Grundtvig - tale om en anden kvalitet, en anden gyldighed hos mennesket i Kristus. 
Dette dobbelte synspunkt, afhængig af perspektivet, finder jeg også udtrykt i afsnittet “c) Discipelen" under punkt B i kap. I i Philosophiske Smuler af Johannes Climacus fra 1844. I det foregående afsnit har Climacus udviklet, hvorledes ethvert menneske sokratisk set har sandheden, medens intet menneske kristeligt set kan have sandheden, men er uden for sandheden, er i usandheden. Mennesket eller, som Climacus her kalder det, den lærende kan derfor ikke sokratisk erindre sandheden med en lærer som anledning; det skal have sandheden givet, ikke af en lærer, men af Guden i tiden, som Climacus kalder Kristus, ja, ikke nok med det, Guden skal også give mennesket betingelsen med, for at det kan forstå sandheden. Pointen er samtidig, at vel har mennesket som skabt af Gud fået givet betingelsen af ham for at forstå sandheden, men det har tabt denne betingelse; og dette tab er ikke sket på grund af Guden, men i kraft af mennesket selv. Og da tabet er menneskets egen skyld, bliver usandheden polemisk vendt mod sandheden, og da mennesket har udelukket sig selv fra sandheden, er det ufri, bundet, bundet af synden, og kan ikke løse sig selv, men skal genløses, frigøres udefra, af Guden i tiden som forsoner. ${ }^{64}$

$\mathrm{Nu}$ følger så den udtalelse, som er af betydning i vores sammenhæng:

Naar Discipelen er Usandheden (og ellers gaae vi jo tilbage til det Socratiske), men dog er Menneske, og han nu faaer Betingelsen og Sandheden, da vorder han jo ikke først Menneske, thi det var han; men han vorder et andet Menneske, ikke i den spøgende Forstand, som blev han en Anden af samme Qvalitet som tidligere, men han bliver et Menneske af en anden Qvalitet, eller, som vi og kunne kalde det, et nyt Menneske. ${ }^{\circ 65}$

Her er der altså på én gang tale om, at mennesket som skabt er menneske både før og efter tildelingen af betingelsen og sandheden (før og efter genløsningen), og at det bliver et nyt menneske af en anden kvalitet efter genfødelsen, dog ikke nyt i forhold til det skabte, men nyt i forhold til det tabte, så det nu bliver et andet menneske med en kvalitet, der er en genfødelse, altså en fornyelse af den medskabte, men i synden tabte kvalitet. Det er vigtigt her at bemærke, at Climacus et øjeblik efter modstiller den mulighed, at mennesket ved sokratisk fødselshjælp kan føde sig selv, og den nødvendighed, at mennesket kristeligt set ved genfødelsen fødes i kraft af Guden. Og denne genfødelse bestemmes netop som den overgang fra ikke at være til at være, der sker i den forandring, der foregår med mennesket, når det modtager betingelsen og sandheden. Men Climacus kan også kalde denne forandring for den omvendelse, der finder sted i det enkelte menneske, når det efter at have modtaget betingelsen og sandheden vendes om for selv at kunne vende om, så det nu i stedet for at gå bort 
fra sandheden går bort fra usandheden, dvs. det bliver sig sin skyld bevidst, vender blikket bagud, dvs. det angrer, mens det går fremad i retning af sandheden. Der er her fastholdt en dialektik mellem en skabelsesteologisk synsvinkel med et kristologisk fortegn og en kristologisk synsvinkel med et skabelsesteologisk fortegn.

Ligheden og modsætningen til Grundtvig findes i ét og samme udsagn: "Menneske-Livet, før og efter Syndefaldet og før og efter Gjenfødelsen, er aldeles eensartet og igrunden det selvsamme". ${ }^{66} \mathrm{Og}$ dog synes Grundtvig at modificere 'aldeles' med 'i grunden'. Hvis man tør, og det vover jeg, at tage udsagnets parallelitet på ordet, så er menneskelivet før og efter syndefaldet 'aldeles ensartet', mens menneskelivet før og efter genfødelsen er 'i grunden det selv samme', altså nok det samme og dog ikke helt det samme. Den sidste tolkning mener jeg at kunne finde $\mathrm{i}$ al fald to belæg for.

Dels i Den christelige Børnelceredom i afsnittet om "Det medfødte og det gienfødte Mennneskeliv". Her skriver Grundtvig, at det

kan og skal bestandig klarere indsees, at det medfødte og det gienfødte Menneske-Liv vel er saa himmelvidt forskiellige, som Beskaffenheden, Vidden og Graden af de høiere Livs-Krafter, af Sandfardigheden og Sandheden og af Kicerligheden og Godheden, hvorved Menneske-Livet udtrykker sig i Menneske-Talen, men

skynder han sig at tilføje,

at det dog paa den anden Side altid er det selvsamme Menneske-Liv, vi taler om, med de samme Love og oprindelige Egenskaber, de samme Livs-Kræfter og Kiendemærker. ${ }^{67}$

Dels i den sidste strofe i salmen "Hvor skal jeg Guds Billed finde?" Her er, som jeg tidligere har påpeget, opfattelsen den, at Gud i Jesu navn velsigner sit billede i mennesket med sin Ånd, så det som hans barn kommer til at ligne ham og således kommer til "at see med Øine ny". Og med dette nye syn, Kristus-troens nye syn, kan mennesket nu se klart, hvad der "end skjuler sig bag Sky", at Guds åsyn er evigt mildt.

Det er ikke mit sigte at urgere en bestemt opfattelse hos Grundtvig. Men der er dog i Den christelige Børnelardom tale om en himmelvid forskellighed mellem det medfødte og det genfødte menneskeliv, hvad dets beskaffenhed angår. Ligesom der i salmen er tale om, at Gud med sin Ånd fornyer eller genopretter gudligheden i mennesket og forlener det med et nyt syn. At kalde det en kvalitetsforskel mellem før og efter vil nok være at gå for langt og presse Grundtvig ind i et ordvalg, han ikke selv ville anvende; han ville formentlig foretrække en sprogbrug, der udtrykte en dynamisk vækst fra det medfødte til det genfødte, en 
vækst, der så at sige griber bag om genfødelsen og funderer den i skabelsen, så "Gienløsningen i Tidens Fylde" knytter sig "uopløselig til Skabelsen i Tidens Ophav", ${ }^{68}$ men dog også en vækst, der har kvalitative brudflader mellem livet før syndefaldet og efter genfødelsen.

Forskellen - snarere end modsætningen - mellem Grundtvigs og Kierkegaards menneskesyn ligger ' $i$ grunden' i deres forskellige synsfelt og hovedærinde. Mens Grundtvig vægter den skabelsesteologiske vinkel højest, lægger Kierkegaard vægten på den kristologiske - som dog dybest set hos dem begge udspringer af en trinitarisk grundanskuelse. Og den tolkning, at de er fælles om et mere optimistisk syn på mennesket før og efter syndefaldet end det traditionelt lutherske, tør jeg godt fremsætte - i det mindste som en tese til videre overvejelse og diskussion.

\section{Guds lighed i mennesket}

Udgangspunktet er dels 1 Mos 1,26: "Og Gud sagde: lader os giøre Mennesket i vort Billede, efter vor Lignelse", dels Grundtvigs og Kierkegaards fælles opfattelse af mennesket som en trehed af legeme, sjæl og ånd. Og videre, at de i min tolkning - på baggrund af Irenæus - er forholdsvis enige om, at Guds billede bæres i sjælen og Guds lighed $\mathrm{i}$ ånden, og at mens gudbilledet er delvis bevaret efter syndefaldet, så er gudligheden gået helt tabt på grund af syndefaldet. ${ }^{69}$ Sigtet er en påvisning af, at mennesket genforlenes med Guds lighed, når det genforenes med Guds Ånd. Og synsfeltet er kristologisk.

Jeg vil her kort inddrage Kristushymnen i Fil 2,5-11:

Thi det samme Sindelag være i Eder, som og var i Christo Jesu, / hvilken, der han var i Guds Skikkelse, ikke holdt det for et Rov at være Gud liig; / men han forringede sig selv, i det han tog en Tieners Skikkelse paa, og blev Mennesker liig; / og da han var funden i Skikkelse, som et Menneske, fornedrede han sig selv, saa han blev lydig indtil Døden, ja Korsets Død. / Derfor haver og Gud høit ophøiet ham, og skienket ham et Navn, som er over alt Navn; / at i Jesu Navn skal hvert Knæ bøie sig, deres i Himmelen, og paa Jorden og under Jorden, / og hver Tunge skal bekiende, at Jesus Christus er en Herre til Gud

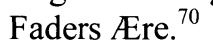

Dette citat kan tjene til at påpege betydningen af Kristi gudligelighed som afgørende i frelsesværket i forhold til menneskets tabte gudlighed. Vel blev Kristus ved med "at være Gud liig", men han forringede sig selv for i skikkelse af en tjener at blive "Mennesker liig". Det er en flot parallelitet mellem "Gud liig" og "Mennesker liig", 1819oversættelsen skaber, men den er både sprogligt og teologisk uholdbar; de to udtryk, at Kristus er lige med Gud, og at han ligner mennesker, er ikke ligebyrdige. ${ }^{71}$ I sin ringhed tog Kristus menneske-ligheden på 
sig og gjorde sig lige-stillet med mennesket, som har tabt gudligheden, der netop ikke er en gudligelighed, men en gudlignelighed. Og det gjorde han for gennem sin lidelse og død og dermed overvindelse af syndefaldet og dets følger at give mennesket mulighed for at få del i hans ligelighed med Gud, så det atter kan komme til at ligne Gud. Spørgsmålet er nu, hvornår og hvordan mennesket genforenes og genforlenes med sin tabte gudlignelighed.

Jeg lader Grundtvig komme til orde først ved at vende tilbage til salmen "I Begyndelsen var Ordet, / Var guddommeligt hos Gud". ${ }^{2}$ Om end disse to indledende linier refererer til de første to vers af Johannesevangeliet, svarer de meningsmæssigt til de første vers af Kristushymnen om Kristi guddommelighed. Jeg har allerede gennemgået stroferne to og tre, hvor der $\mathrm{i}$ den tredje var tale om, at 'genlydsordet' i menneskets vildfarelse blev afskåret fra sin rod. Med fjerde strofe sker vendepunktet i salmen:

Men Guds Ord i Tidens Fylde,

Selv blev Kjød og Blod paa Jord,

Lod sig af Guds Engle hylde,

Svøbt i Støvets Gjenlyds-Ord.

Guds Ord er her Kristus, der med en henvisning til Gal 4,4 blev sendt af Gud, da tidens fylde kom, og blev født af en kvinde, og som med en henvisning til juleevangeliet i Luk 2,1-14 blev hyldet af englene, efter at han var født og blevet svøbt og lagt i en krybbe af sin mor. Ved at lade Kristus svøbe i 'genlydsordet', der her ligefrem synes at stå som synonym for mennesket, udtrykker Grundtvig, at Kristus kom til at ligne mennesket. Efter at have fastslået, at da oprandt "Nyaars-Tiden", modellerer Grundtvig videre i femte strofe over det samme tema:

Da i Kjærlighedens Baand,

Guddoms-Ordet fra det høje

Ydmyg sig vil sammenføje

I et Himmerig paa Jord

Med det matte Gjenlyds-Ord

Paa Jordklimpens Tunge.

Selv om Grundtvig fastholder 'ordet' som tema, så genspejler denne del af strofen dog også Kristushymnen: Kristus som 'guddomsordet' ydmyger sig og føjer sig sammen med det matte 'genlydsord' svarende til, at Kristus i sin guddomme-lighed forringer sig selv, gør sig ligestillet med mennesket og viser sig i menneskeskikkelse. Det bemærkes, at Grundtvig fastholder sit syn, at mennesket har bevaret 'genlydsordet', om end det har tabt noget af sin klang og lyder mat. Vi følger Grundtvig et skridt videre i strofe seks: 
I Begyndelsen Guds-Ordet

Gik med Lue-Tunger ud

Ved Aands-Badet og Guds-Bordet

Som Gud Faders Sendebud,

Med al Glæden og alt Gavnet,

Svøbt i Jesus-Kristus-Navnet,

Til hvert Hjærte, som vil tro,

At Guds Aand hos Kjød kan bo

Med Guds Søn i Ordet.

Denne strofe spiller en afgørende rolle i mit forehavende, for her inddrages Guds Ånd, Helligånden. Med en hentydning til pinseunderet i ApG 2,1-13 er talen nu om, at i kirkens første dage blev 'GudsOrdet', evangeliet, sendt ud i verden som Faderens sendebud for at bringe glæde og gavn i Jesu Kristi navn ved "Aands-Badet og GudsBordet" til ethvert menneske, der med hjertet tror, at Guds Ånd sammen med Guds Søn kan tage bolig hos det skabte menneske i ordet. Hvad det sidste 'i ordet' betyder, ved jeg ikke, men jeg formoder, at det sigter til videreformidlingen af ordet, altså til de troendes forkyndelse af evangeliet. I så fald er der ikke længere tale om et mat 'genlydsord' af skaberordet, men om en klar gengivelse af Kristusordet, af evangeliet om Kristus. Når det døbte og troende menneske evner det, skyldes det ikke blot, at Guds billede er blevet helet, så 'genlydsordet' har genvundet sin klare klang, men det skyldes i højere grad, at dåben er et 'åndsbad'. Ved dette bad bliver den døbte af Helligånden genfødt til "Barne-Lighed med vor Fader", som gudligheden blev kaldt i Christenhedens Syvstjerne. Og ved at Helligånden nu tager bolig i det menneske, der tilegner sig dåben i tro, genforenes dets ånd med Guds Ånd.

$\mathrm{Nu}$ kan Grundtvig endelig i ottende og sidste strofe henvende sig direkte til menigheden, til "Guds-Menigheden", og enhver "kristen Sjæl i den" og opfordre den til at lægge godt mærke til, at både Guds nåde og Guds fred driver hastigt forbi som skyer, medmindre nåden og freden gribes i "Guds-Ordet". Og da det skal gribes "ved Badet og ved Bordet", må 'Guds-ordet' her vel sigte til trosbekendelsen og indstiftelsesordene - og/eller Kristus. Men det skal ikke blot gribes, det skal:

Gjemmes vel af Hjærtets Tro,

Til i Jesu navn at bo

Hos os med Guds-Ordet!

Altså er det, der sker ved dåb og nadver, altafgørende både for menigheden og for det enkelte kristne menneske i menigheden. Og det skal i den grad tilegnes, at det bevares i troen. Altså synes badet og bordet for Grundtvig på én gang at være det, der konstituerer menigheden, og det, som udgør den enkeltes frelseshistorie. 
Inden jeg delkonkluderer, vil jeg citerer tre strofer (fire, fem og syv) om henholdsvis dåben og nadveren fra salmen "Herrens Røst er over Vandet". ${ }^{73}$

Herrens Røst er over Vandet, Herrens Røst med Aand og Ord, Herrens Røst, og intet andet, Igjenføder Liv paa Jord;

Den kan Ild og Vand forene

Til et Væld med Straaler rene:

Vandspring til et evigt Liv.

Herrens Røst er over Daaben, Aandens Vandbad i Guds Ord, Deraf under Himmel aaben

Fødes nyt og godt paa Jord:

Underfuldt, paa Aandens Maade, Kristen-Livet af Guds Naade,

Aandens Frugt er Aandens Segl.

Bortset fra, at Grundtvig her taler om både genfødelse og nyfødelse (det sidste skal jeg komme tilbage til senere), så betoner han ordets og åndens samvirke ved dåben endnu stærkere end $\mathrm{i}$ den foregående salme. Og når han siger, at 'åndens frugt', altså virkningen af Helligånden ved dåben, er 'åndens segl', så forstår jeg dette segl, indpræget af ånden, som endnu et udtryk for gudligheden, der enten genfødes eller nyfødes i mennesket.

Herren Røst er over Bordet

I sin Kraft og Herlighed,

I sin Fylde der Livs-Ordet

Som Guds Manna drypper ned;

Kjærlighed og Sandhed sammen

Nydes der med Fryd og Gammen,

Som Guds Vin og Himlens Brød.

Konklusionen af denne gennemgang kan munde ud i følgende skematiske opstilling, at der hos Grundtvig er en akse mellem dåben og nadveren. Dåben forstået dels som en dåb til Kristi død og oprejsning, ${ }^{74}$ dels som et åndsbad, hvor Guds billede i sjælen heles eller genfødes, og hvor Guds lighed i ånden genoprettes eller nyfødes ved Helligånden, så menneskets 'synde-skyld' som en følge af syndefaldet er tilgivet og udslettet. ${ }^{75} \mathrm{Og}$ nadveren forstået som kærlighedens og sandhedens nådebord, hvor den troende i måltidet modtager Kristus som brødet fra himlen og får del i det evige liv. I dåbshandlingen er det især Helligånden og i nadverhandlingen især Kristus, der 
er virksom gennem ordet, og ved begge handlinger skal Guds fred og Guds nåde gribes og tilegnes $i$ tro.

$\mathrm{Nu}$ kommer så turen til Kierkegaard. Her vil jeg lægge ud med et tekstafsnit fra den anden af de tre taler Hvad vi laere af Lilierne paa Marken og af Himmelens Fugle, anden afdeling af Opbyggelige Taler $i$ forskjellig Aand. ${ }^{76}$ Temaet i denne tale er: "hvor herligt det er at være Menneske", og det behandles på baggrund af Jesu retoriske spørgsmål i Matt 6,30: når nu Gud klæder markens græs, som kun står én dag for at blive brændt den næste, "skulde han saa ikke meget mere klæde Eder I lidet Troende!" som det frit gengives i talen. Pointen er, at det egentlig ikke handler om klædningsstykker, men om selve påklædningen, som er det at være menneske, og som ikke skyldes mennesket, men Gud. Denne herlighed finder Kierkegaard kort og samlet udtrykt $\mathrm{i}$ ét eneste ord, "hvilket Skriften selv bruger med Myndighed: Gud skabte Mennesket $i$ sit Billede". Skønt liljen overgår Salomo i al hans pragt, så ligner den dog ikke Gud, og netop derfor er mennesket uendeligt herligere end liljen, fordi det ligner Gud. Hermed har vi altså vore to udtryk: Guds billede og Guds lighed i spil; og spørgsmålet bliver, om Kierkegaard skelner imellem dem eller forstår dem som to sider af samme herlighed.

Efter at have reflekteret over, hvordan billedet af et menneske, der spejler sig $\mathrm{i}$ havets overflade, forsvinder, når mennesket fjerner sig havspejlet er altså ikke billedet og kan heller ikke fastholde billedet, når skikkelsen fjerner sig - fortsætter han:

Men Gud er Aand, er usynlig, og Usynlighedens Billede er jo atter Usynlighed: saaledes gjengiver den usynlige Skaber sig $\mathrm{i}$ den Usynlighed, hvilken er Aandens Bestemmelse, og Guds Billede er netop den usynlige Herlighed. Var Gud synlig, ja da var der Ingen, der kunde ligne ham eller være hans Billede; thi alt Synligts Billede er ikke til, og blandt alt det Synlige er der Intet, end ikke et Blad, der ligner det Andet eller er dets Billede, var det Tilfældet, da var Billedet Gjenstanden selv. Men da Gud er usynlig, saa kan Ingen synligt ligne ham; just derfor er det at Lilien ikke ligner Gud, fordi Liliens Herlighed er den synlige,

hvorimod mennesket kan ligne Gud, da "den usynlige Gud skabte hvert Menneske i sit Billede" 77

Kierkegaards hovedanliggende er her: Dels at få understreget Guds usynlighed, for ellers ville mennesket hverken kunne ligne ham eller være hans billede, og så ville dets herlighed være intet, dels at få hindret muligheden for at kunne identificere Gud med billedet af Gud, for ellers ville man kunne slutte sig fra Guds billede til Gud selv, og så ville Gud jo ikke være usynlig, men synligt kendt. Der er endnu et vigtigt anliggende, det nemlig at undgå, at menneskets gudbilled- 
lighed skulle være synligt, for så ville det jo sidde i det synlige legeme, hvilket det netop ikke gør, det sidder derimod i den usynlige sjæl og usynlige ånd.

Bag om dette anliggende mener jeg dog - på baggrund af det allerede udviklede - forsvarligt at kunne finde den opfattelse, at Guds billede har sæde i sjælen og Guds lighed i ånden. Og for den opfattelse finder jeg støtte i det følgende. Umiddelbart efter det citerede stykke, siger Kierkegaard både som en konklusion på det forudgående og som en indledning til det efterfølgende: "At være Aand, det er Menneskets usynlige Herlighed." Dette kædes nu sammen med, at menneskets tilbedelse af Gud netop er det, hvorved mennesket ligner Gud. Uden for kristendommen identificeres ligheden med det at herske, men inden for kristendommen med det at tilbede. Og det skyldes, kristeligt set, at ligheden kun er sand, hvis den ligger i "den uendelige Forskjellighed", nemlig mellem Gud som skaber og mennesket som skabt. Mennesket ligner først i sandhed Gud, når det altid er den tilbedende og Gud altid, evigt er den allestedsnærværende genstand for tilbedelsen. Vil mennesket derimod ligne Gud ved at herske, da har det glemt Gud, "da er Gud gaaet bort, og Mennesket leger Hersker i hans Fraværelse.,"78 Og det er netop, hvad menneskets liv er uden for troen på Gud, et liv i fraværelse af Gud, fordi det selv har afskåret sig fra gudligheden i ånden og dermed adskilt sin ånd fra Guds Ånd. Og - kunne man tilføje med et tilbageblik til beskrivelsen i Begrebet Angest af frihedens fejlgreb og skyldens opståen - fordi mennesket, da det i frihedens mulighed skulle gribe, greb endeligheden i stedet for uendeligheden, altså sig selv at holde sig til som hersker over sit eget liv i stedet for Gud at holde sig til som skaber af og hersker over alt liv. Derved blev gudbilledet i sjælen beklikket og spaltet $\mathrm{i}$ tvesindethedens uvilje til at ville ét, ville Guds vilje.

Spørgsmålet er nu, om dåb og nadver indtager den samme centrale betydning for fornyelsen og genoprettelsen som hos Grundtvig. Et første svar er, at mens Grundtvig fastholder en klar akse mellem dåb og nadver, så indskyder Kierkegaard et tredje moment, skriftemålet, så skemaet bliver: dåb, skriftemål, altergang.

Dåben har ikke den signifikante placering i Kierkegaards teologi, som den har hos Grundtvig. Og mens Grundtvig først og fremmest understreger dåben som et genfødelsens åndsbad og dernæst forstår den som en pagt, så accentuerer Kierkegaard den stort set kun som en pagt. ${ }^{79}$ Vel er de enige om, at dåben skal tilegnes i tro, ${ }^{80}$ men mere end Grundtvig urgerer Kierkegaard, at mennesket konstant falder ud af og bryder pagten. Det er her den skriftendes syndsbekendelse og den absolveredes modtagelse af Guds tilgivelse i skriftemålet får sin afgørende betydning som en nærmest nødvendig forberedelse til og 
forudsætning for at kunne gå værdig til alters. At Kierkegaard ikke tillægger barnedåben nær den betydning som Grundtvig, skyldes hans opgør med den traditionelle forståelse af arvesynd; i stedet træder skriftemålet til eller lægger sig imellem som en form for bekendelsesog trosdåb.

Skriftestolen - sådan kaldte man dengang det afsondrede rum, hvor skriftemålet fandt sted ${ }^{81}$ - er i Kierkegaards forståelse ikke en domstol, men et selvbesindelsens, selvprøvelsens og selvfornægtelsens aflukke. Den enkelte skriftesøgende er ikke sat under anklage af nogen anden end af sin egen samvittighed, da det netop er samvittigheden, der taler anklagende til og om mennesket i dets indre, ${ }^{82}$ og denne selvanklage er muligheden for, ja, betingelsen for, at Gud skal erklære den enkelte retfærdiggjort. ${ }^{83}$ Efter at have besindet, prøvet, anklaget og fornægtet sig selv gør den syndbevidste enkelte regnskab for og bekender sin synd og sine troskabsbrud over for Gud og søger således angrende forligelse med $\mathrm{Gud},{ }^{84}$ hvorpå den enkelte modtager sine synders forladelse af Gud i absolutionen.

Herefter kan den nu absolverede forlade skriftestolen og af trang efter Kristi kærlighed modtage hans indbydelse, når han ved alteret breder sine arme ud og siger: "Kommer hid alle I, som arbeide og ere besværede, og jeg vil give Eder Hvile." ${ }^{\prime 85}$ Ved alteret er det Kristi egen røst, der lyder - ikke som i prædikenen præstens, og her er Kristus selv personligt til stede. ${ }^{86}$ Som indbyderen møder han den nadversøgende med den forsoningens trøst, at han - nåden og nådens giver - fyldestgørende har sat sig i menneskets sted og nu som fyldestgører dækker, skjuler menneskets synd med sin lidelse og død, hvorfor brødet og vinen dels er pantet på, at Kristus er død 'for mig', dels er pantet på det evige liv. ${ }^{87}$ Alteret er retfærdiggørelsens sted; dér effektueres den retfærdiggørelse, som af Gud er erklæret i skriftestolen, ${ }^{88}$ og dér modtages $\mathrm{i}$ brødet og vinen pantet på, at den enkelte har fået syndernes forladelse, ${ }^{89}$ som er tildelt i skriftestolen, så denne enkelte nu i nadveren selv kan tage imod den og tilegne sig den. ${ }^{90} \mathrm{Og}$ det troskabsløfte, som er givet og aflagt ved dåben, og som den angrende i skriftestolen har bekendt sit brud på, fornyr Kristus ved alteret over for den enkelte, ligesom den enkelte på sin side fornyr det over for Kristus, hvorved den enkelte genforenes $i$ et fornyet fællesskab med Kristus. ${ }^{91}$

Velsignet af Kristus kan den enkelte nu gå bort fra alteret, "saa, gudelig forstaaet, let om Hjertet som et nyfødt Barn, paa hvem Intet, Intet tynger, altsaa endnu lettere om Hjertet, forsaavidt meget har tynget paa Dit Hjerte". ${ }^{92} \mathrm{Og}$ idet den enkelte forlader alteret for at vende tilbage til sin hverdag, bliver han fulgt af Kristus for at følge og efterfølge ham. ${ }^{93}$ 
Den længsel efter Gud, som får den syndsbevidste til at opsøge Gud i skriftestolen er "Aandens Virken" i den enkelte. ${ }^{94}$ Denne længsel kan Kierkegaard også kalde "Sorgen efter Gud", der formentlig har dobbelt betydning, dels en sorg ifølge Guds vilje, dels en sorg over syndens adskillelse fra Gud, ${ }^{95}$ men $\mathrm{i}$ begge tilfælde skal denne sorg eller bedrøvelse lede til omvendelse og syndsbekendelse (jf. 2 Kor 7,911) og altså ind i skriftestolen. Ved alteret derimod er det Kristus, der drager den angergivne til sig, men gennem syndsbevidstheden, hvilket jo betyder, at vejen netop går gennem skriftestolen til alterbordet, og $\mathrm{i}$ denne syndsbevidsthed føler mennesket sig allerede draget. ${ }^{96}$ Her er der altså en dobbeltbevægelse, hvor første led i bevægelsen er menneskets syndsbevidste følelse af at længes efter Gud, være draget til Gud og trænge til Gud svarende til den rest af Guds billede, der er forblevet i menneskets sjæl. Men når Ånden skal træde virkende til, forstår jeg det som udtryk for, at Guds lighed i ånden derimod er gået helt tabt.

Det, der sker i skriftestolen, er en genoprettelse af dåbspagten og en fornyelse af gudbilledet i kraft af Guds syndsforladelse med en fornyelse af den tabte frihed til følge, en ny frihed, som gør, at mennesket nu værdigt kan gå til alters. Og det, der sker ved alteret, er en gensidig bekræftelse af troskabsløftet fra dåben og en fornyelse af gudligheden $\mathrm{i}$ ånd og sandhed i kraft af Kristi stedfortrædende forsoning og fyldestgørelse. Den tidligere omtalte kvalitetsforskel før og efter fornyelsen kan også spores her, for så vidt som Kierkegaard kan tale om, at det er den samme tro og den samme kærlighed før og efter frelsen, dog er den anden stærkere end den første. ${ }^{97}$

Hos Grundtvig spiller skriftemålet ikke denne afgørende rolle. I Den christelige Børnelaerdom gør han rede for, at han en tid lang egentlig havde ønsket skriftemålet afskaffet, da det ikke af Helligånden er sat i klar sammenhæng med dåben og nadveren, men kun er en "Kirkeskik med dunkel Oprindelse og tvivlsom Christelighed". I al fald er han imod afløsning af synden i skriftemålet uden personlig syndsbekendelse og uden mulighed for kirketugt. Men hvad værre er, ved at bevare skriftemålet kommer man til at flytte syndsforladelsen fra dåben til skriftestolen og til alterbordet. $\mathrm{Og}$ for Grundtvig er det aldeles afgørende at fastholde, at syndsforladelsen skænkes helt og fuldt $\mathrm{i}$ dåben. Ja, han gør endog op med den traditionelle lutherske dåbsforståelse og kalder det ligefrem åndløst at bilde sig ind, "at Arve-Synden, som er den nedarvede Syndighed, virkelig kan forlades uden at alle denne Syndigheds nødvendige Følger og Virkninger forlades med det samme”, hvorfor det også er åndløst at bilde sig ind, at tilsigelsen af syndernes forladelse skal "gientages ved hver Altergang, for at beholde Kraft og Gyldighed". Den fulde og fuldt 
dækkende syndsforladelse er nemlig en forudsætning for, at det syndige menneske kan modtage Helligånden og genfødes og fornys $\mathrm{i}$ Guds billede. Dog nåede Grundtvig efterhånden til en ny forståelse af skriftemålet, ikke således at forstå, at der skulle være tale om en deling af syndsforladelsen mellem dåb og nadver, men således at forstå, at der er tale om en dobbelt syndsforladelse, den guddommelige, som skænkes i dåben, og den menneskelige, som hører til nadveren; og ved den menneskelige forstås den indbyrdes tilgivelse af hinanden. Dette bygger Grundtvig dels på den femte bøn i Fadervor, hvor "vi beder vor himmelske Fader forlade os vor Skyld, som vi forlade vore Skyldnere", dels på Jesu lignelse om den gældbundne tjener i Matt 18,23-35, hvor han har vidnet for sine disciple, "at dersom de ikke indbyrdes tilgive hverandre deres Skyld, da vil den himmelske Fader ikke heller tilgive dem deres". Grundtvig udkaster derfor den "rimelige" antagelse, at der i den apostolske menighed har fundet en sådan udtrykkelig indbyrdes syndstilgivelse sted ved nadveren, meddelt af den ældste, som forestod nadveren. Denne apostolske skik vil Grundtvig nu henlægge til skriftemålet, som derfor hverken skal afskaffes eller adskilles fra nadveren, men føres tilbage til sin kristelige betydning "som aandelig 'Fodtvæt' og hjerteligt 'Broderkys' til Udtryk af den Kiærlighed, som skjuler Synders Mangfoldighed". 98

Men det er og bliver dåben, der er helt afgørende i Grundtvigs frelsesforståelse. I dåben dør og opstår den døbte med Kristus, skænkes den fulde og fuldt dækkende syndsforladelse og genfødes ved Helligånden til at få helet Guds billede og fornyet Guds lighed, hvorved den enkelte indfældes i Kristus-fællesskabet i menigheden. Den pagt, der sluttes ved dåben, skal i troen tilegnes, og sker det, lever mennesket båret af fællesskabet, og kan i nadveren modtage brødet og vinen til livskraft her på jorden og til evigt liv i himlen. ${ }^{99}$ Ifølge Kierkegaard skal dåbspagten også tilegnes i tro, men her er den enkelte mere overladt til sig selv uden støtte i et menighedsfællesskab, og den enkelte falder gang på gang ud af pagten og svigter troskabsløftet, hvorfor pagten skal genoprettes i skriftemålet og løftet fornys i nadveren.

\section{Fornyelse eller nyskabelse}

Et par gange har jeg været inde på, om der, især hvad angår den tabte gudlighed, er tale om en fornyelse eller om en nyskabelse, og jeg har argumenteret for den opfattelse, at såvel Grundtvig som Kierkegaard vælger tanken om en fornyelse frem for forestillingen om en nyskabelse i Kristus, og at ingen af dem opererer med en anden 'creatio ex nihilo'. Jeg vil her til sidst, for en ordens skyld, problematisere denne opfattelse og antyde, at der kan findes belæg for en omvendt prio- 
ritering af de to begreber også set i forhold til gudbilledet - for mig overraskende nok mere hos Grundtvig end hos Kierkegaard.

Som sædvanlig Grundtvig først. Da der kun er tale om en antydning, indskrænker jeg mig til at give tre eksempler i kronologisk rækkefølge. Først fra salmen "Stod med Krist vi op af Døde" (1836), hvor strofe seks lyder:

Bort med gamle Adams Klæder!

Vandre vil i os den ny,

Som kun Lysets Vej betræder

Under Sol, som over Sky;

I Guds Billed vi, nyskabte,

Vise skal, hvad Adam tabte. ${ }^{100}$

Her er der netop tale om en nyskabelse af Guds billede, og det er det, fordi det er tabt i Adam på grund af syndefaldet. Om Grundtvig i virkeligheden tænker på Guds lighed i stedet for Guds billede, tør jeg selvsagt ikke påstå, selv om jeg gerne ville. Det andet eksempel er fra tredje og sidste strofe i julesalmen "Guds Engle i Flok! synger liflig i Kor" (1849):

Al Æren er Guds over højeste Sky,

For den glade Jul,

I Billede sit har han skabt os på ny,

Med Jesus, vor Helt og vor Herre! ${ }^{101}$

Det sidste eksempel er fra salmen "Dybt fornedres skal enhver". ${ }^{102}$ Heri findes flere af de elementer, vi tidligere har været inde på. I den anden strofe er der således tale om, at Adam blev skabt i Guds billede og var "sin Skabers Næste", vel udtryk for, at han, som det hed i den refererede prædiken, kunne tale med Gud som en mand med sin næste. Dog vendte Adam Gud ryggen, blind for sit eget bedste som han var, og fortabt i sig selv styrtede han ud af Edens Have og ravede til afgrunden. I den tredje strofe spiller Grundtvig, som vi tidligere har set, på Kristushymnen i Filipperbrevet, at Kristus "i Guds Herlighed / Var sin Faders Lige", men at han ydmygede sig og steg ned til "de smaa" for at hente dem "fra Afgrund op", den afgrund, som mennesket på grund af syndefaldet åbenbart må være faldet ned i eller i al fald befinde sig på randen af. Jeg springer til femte strofe:

Vend dog om fra Afgrunds Rand,

Hver en Sjæl forvildet!

Tro paa Jesus, Gud og Mand,

Gud i ham formildet!

Læg som Støv dig i Guds Haand!

Da opliver dig Guds Aand 
Atter i Guds Billed.

Selv om Grundtvig ganske vist ikke bruger udtrykket nyskabe, så er det dog snarere forestillingen om en nyskabelse end om en fornyelse, der ligger nærmest for. Mennesket skal jo atter blive som støv, så Gud kan (ny)danne det og (gen)oplive det ved at indblæse sin livsånde i det (jf. 1 Mos 2,7), så det atter kan blive et levende Guds billede. Dette sidste eksempel står som en art mellemproportional mellem fornyelse og nyskabelse, en genskabelse kunne man måske med rette sige, og det viser, hvor forsigtig man trods alt skal være med at gøre Grundtvig alt for entydig - vel også rimene taget i betragtning. Dog hefter jeg mig ved, at der i den sidst citerede strofe ikke er tale om en 'creatio ex nihilo'.

Hvad Kierkegaard nu angår, vil jeg vende tilbage til 2 Kor 5,17: "dersom Nogen er i Christo, da er han en ny Skabning: det Gamle er forbiganget, see, Alt er blevet nyt" (i 1819-oversættelsens ordlyd). Selv om Kierkegaard normalt kun taler om, at "Alt er nyt i Christo" eller blot "Alt er nyt", så kender han selvsagt sammenhængen; men det er dog bemærkelsesværdigt, at han yderst sjældent citerer verset i sin helhed og medtager formuleringen "en ny Skabning".

Dog er der undtagelser i den forstand, at der kan være tale om at skabe et nyt menneske. Således hedder det i slutningen af den første tale, "At trænge til Gud er Menneskets høieste Fuldkommenhed", i Fire opbyggelige Taler (1844):

Som det at kjende sig selv i sin egen Intethed er Betingelsen for at kjende Gud, saaledes er det at kjende Gud Betingelsen for, at et Menneske ved hans Bistand helliggjøres efter sin Bestemmelse. Hvor Gud er i Sandhed, der er han altid skabende. Han vil ikke at Mennesket i aandelig Blødagtighed skal bade sig i Beskuelsen af hans Herlighed, men han vil, ved at vorde kjendt af Mennesket, skabe i ham et nyt Menneske. ${ }^{103}$

Dog drejer det sig netop ikke om, at Gud nyskaber mennesket, men om, at han skaber et nyt menneske i mennesket; skabelsesteologisk set er mennesket det samme, men helliggørende set er det et nyt menneske. Det er altså ikke en nyskabelse, men snarere en omskabelse eller forandring af det skabte menneske, det handler om. Til fordel for at forstå det nye som en forandring taler følgende citat fra samme tale:

Saa vil da lidt efter lidt, thi Guds Naade tages aldrig med Vold, det menneskelige Hjerte i skjøn Forstand blive mere og mere unøisomt, dvs. mere og mere higende, mere og mere længselsfuldt efter at vide sig Naaden sikkret. Og see, nu er Alt blevet nyt, Alt blevet forandret! ${ }^{104}$ 
I øvrigt kan Kierkegaard, om end i en lidt anden kontekst, i den følgende tale sige om Paulus, at "han var i sjelden Forstand blevet et andet Menneske, en ny Skabning, han havde ikke blot forandret Navn [nemlig fra Saulus til Paulus], men i en anden Forstand var det dog det samme Menneske."105

Indtil nu har Kristus ikke været inddraget eller i al fald ikke direkte nævnt; det sker i nr. III i "Lidelsernes Evangelium", tredje afdeling af Opbyggelige Taler i forskjellig Aand (1847), hvor det med en række skrifthenvisninger siges til talens tilhører:

tænk Dig nu, at Den, om hvem den hellige Skrift siger, han lærte Lydighed af hvad han leed, det var Ham, som var hos Faderen fra Evighed, det var Ham, som kom i Tidens Fylde, det var Ham, som fuldbragte hvad Faderen havde begyndt, Ham, som fuldendte Skabelsen og omskabte Verdens Skikkelse. ${ }^{106}$

Hvad det betyder, forklarer Kierkegaard bedre i en optegnelse i journalen NB12, end jeg kan, altså tillader jeg mig endnu engang at citere:

just dette er Christendom. Skabelsen er egentlig først fuldendt, idet Gud har anbragt sig selv med. Før Christus er Gud vel anbragt med i Skabningen, men som et usynligt Mærke, ligesom Vand-Mærket i Papir. Men i Incarnationen fuldendes Skabningen derved, at Gud har anbragt sig selv med. ${ }^{107}$

Omsat i forhold til vores kontekst betyder det, at Guds billede og lighed i det skabte menneske er som et vandmærke, der først fuldendes i Kristus; altså ikke nyskabes, men skabes fuldendt.

Nævnes skal det dog, at Johannes Climacus i Afsluttende uvidenskabelig Efterskrift (1846) hævder, at paradoks-religiøst er en discipel af Guden i tiden "en ny Skabning"; men da han netop udtrykkeligt er det i samme forstand, som det kom til udtryk i Philosophiske Smuler, så ved vi fra tidligere, at der ikke er tale om et andet menneske skabelsesteologisk set, men om et menneske med en ny og anden kvalitet kristologisk set. ${ }^{108}$ Jeg ser en parallel opfattelse bragt til udtryk i en samtidig optegnelse i journalen JJ, hvor Kierkegaard kalder syndsforladelsen "den ny Skabning" ${ }^{109}$ Jeg forstår dette, min tolkning tro, som en fornyelse af det gamle skabelsesgivne, men medgiver, at her som andre steder er den fortolkning dog også mulig, at der virkelig sker en nyskabelse af mennesket, når det får sine synder tilgivet. En sådan forståelse må dog til gengæld acceptere, at det tvinger til den opfattelse, at det, Gud har skabt, er blevet tilintetgjort. Og den opfattelse kan jeg ikke følge og heller ikke finde karakteristisk for Kierkegaard. For når det i citatet fra en af de opbyggelige taler hed sig, at mennesket som en betingelse for at kende Gud må kende sig selv som intet, så betyder det jo ikke, at det skabte menneske er intet, 
men at det intet formår i forhold til Gud, af hvem det må modtage alt og helliggøres af nåde. Det drejer sig atter om, hvilken synsvinkel der anlægges. Eksistentielt set er mennesket intet på grund af synden, men ontologisk set er det ikke totalt tilintetgjort på grund af syndefaldet. Kristologisk eller soteriologisk set derimod kan man med rette hævde, at det krakelerede og spaltede gudbillede fornys og den tabte gudlighed nydannes, så det forlenes med en ny kvalitet. Men da det er det skabte menneske, der modtager sine synders nådige forladelse og således får sin 'gamle', måske endda udlevede skabthed fuldbragt, er det kun eksistentielt, ikke dogmatisk set, at der kan være tale om en anden 'creatio ex nihilo'.

\section{Afslutning}

Artiklens tese var, at Irenæus' distinktion mellem imago dei og similitudo dei, hvor Guds billede i sjælen ikke er mistet, mens Guds lighed i ånden er tabt på grund af syndefaldet, så gudligheden skal helliggøres af Ånden, kan genfindes hos Grundtvig og Kierkegaard. Den tese har vist sig ikke at lade sig gennemføre i alle detaljer og for alle tekster, dertil er den for skematisk og statisk opbygget for den dynamisk prægede Grundtvig og den dialektisk bestemte Kierkegaard. Men som en folie for en fremlæsning og samlæsning af deres syn på mennesket set i forhold til syndefaldets konsekvens for dets skabelsesgivne gudbilled-lighed, har den i al fald for mig været en hjælp til at afdække væsentlige aspekter af deres antropologi.

For både Grundtvig og Kierkegaard gælder det, at der i mennesket er et oprindeligt, på forhånd skabelsesgivet guddommeligt præg i form af en gudbilled-lighed, og at dette præg, dette adelsmærke eller vandmærke, ikke er totalt forgået, når det gælder gudbilledet, men tabt, når det gælder gudligheden, skønt de ikke så skarpt som Irenæus gennemfører denne skelnen mellem imago dei og similitudo dei.

Mens der ifølge Grundtvig først og fremmest er tale om, at der på trods af syndefaldet er bevaret noget positivt af Guds billede i form af genlydsordet, som både kan høre og udtale Guds skaberord, er der ifølge Kierkegaard primært tale om, at der på grund af syndefaldet er efterladt noget negativt af Guds billede $\mathrm{i}$ form af en krakeleret og splittet frihed, som dog positivt bliver til syndsbevidsthed og trang efter Gud. For dem begge gælder det, i den udstrækning Irenæus' skelnen kan opretholdes, at der er bibeholdt en rest af Guds billede $\mathrm{i}$ sjælen, mens Guds lighed $\mathrm{i}$ ånden derimod er gået tabt, og at det er Ånden, der er den virkende kraft både i fornyelsen og genforeningen af gudbilledet og gudligheden. Hos Grundtvig sker fornyelsen af gudbilledet og genfødelsen af gudligheden ved Helligånden i dåben; hos Kierkegaard, hvor dåben ikke har den samme signifikante betyd- 
ning, sker det $\mathrm{i}$ et samspil mellem skriftemål og nadver. Der er ikke, i al fald ikke som det gennemgående, hos nogen af dem tale om en nyskabelse at forstå som en anden 'creatio ex nihilo', men netop om en fornyelse, en forandring, en genfødelse, en genløsning, en genoprettelse, en genoprejsning, en gentagelse og en genforening $\mathrm{i}$ ånd og sandhed. Mens Grundtvig, der især tænker dynamisk og billedligt, lægger vægten på den ensartede kvalitet, pointerer Kierkegaard, der mere tænker dialektisk og begrebsligt, den forskelligartede kvalitet før og efter syndefaldet henholdsvis før og efter genfødelsen og fornyelsen. For dem begge er der dog tale om en vækst, hos Grundtvig en vækst $\mathrm{i}$ tro, håb og kærlighed, hos Kierkegaard en vækst i troen og især i efterfølgelsen af Kristus som sandheden, der medfører et helliggørende kærligheds- og lidelsesfællesskab med Kristus.

\section{Standardforkortelser}

Pap. $\quad$ Søren Kierkegaards Papirer, udg. af P. A. Heiberg, V. Kuhr og E. Torsting, bd. I-XI, København 1909-48; 2. forøgede udg. ved N. Thulstrup, bd. I-XVI, København 1968-78. Der henvises til bind, gruppe (A, B eller C) og optegnelsesnummer.

SKS Søren Kierkegaards Skrifter, udg. af Niels Jørgen Cappelørn, Joakim Garff, Jette Knudsen (fra 1998), Johnny Kondrup, Alastair McKinnon og Finn Hauberg Mortensen (indtil 1997), bd. 1-8 + K1-8 og 17-21 + K17-21, København 19972004.

SV2 Søren Kierkegaards Samlede Varker, udg. af A. B. Drachmann, J. L. Heiberg og H. O. Lange, 2. udg., bd. 1-15, København 1920-36.

\section{Litteraturliste}

Dannemarks og Norges Kirke-Ritual (1762), København.

Den Danske Salmebog (1953), København.

DDS 2003 = Den Danske Salmebog (2003), København.

Forordnet Alter-Bog for Danmark (1830), København.

Fortegnelse over den af N. F. S. Grundtvig efterladte Bogsamling, som bortsalges ved offentlig Auction (1873), København.

Fortegnelse over Dr. Søren A. Kierkegaards efterladte Bogsamling som bortscelges ved offentlig Auction (1856), København. 
Grundtvig, N. F. S. (overs., 1827), "Om Legemets Opstandelse og Deel i Guds Rige: Irenæi 5te Bog, med Indledning og Anmærkninger" i Theologisk Maanedsskrift, bind 11, København, 10-61 og 193-282.

Grundtvig, N. F. S. (1837), Sang-Verk til den Danske Kirke, bind 1, København.

Grundtvig, N. F. S. (1854-55), "Christenhedens Syvstjerne" i Dansk Kirketidende, bind 9, 713-25, 761-71, 825-41, og bind 10, 65-78, 217-35, 361-85, 489-509.

Grundtvig, N. F. S. (overs., 1855), Om Kiødets Opstandelse og det evige Liv af Biskop Irenceus, fordansket, København.

Grundtvig, N. F. S. (1868), Den christelige Børnelardom, 2. udg. (optrykt efter Kirkelig Samler. Et Tidsskrift til christelig Oplysning), København.

Grundtvig, N. F. S. (1868-81), Salmer og aandelige Sange, bind 1-5, København.

GPV I = Holm J. et al. (2003), Grundtvig: Praedikener $i$ Vartov, bind 1: 1839-40, København.

Hagen, L. C. (1834), Troens rare Klenodie, i nogle aandelige Sange fremstillet af Hans Adolph Brorson, København.

Irenæus (1702), S. Irenæi Episcopi Lugdunensis Contra omnes Hoereses Libri quinque, udg. og kommenteret af J. E. Grabbe, Oxford.

Kierkegaard, S. (1833-40), "Notesbog 1" i Søren Kierkegaards Skrifter, bind 19 (2001), 5-85.

Kierkegaard, S. (1839), "Journalen EE" i Søren Kierkegaards Skrifter, bind 18 (2001), 5-71.

Kierkegaard, S. (1840-41), "Journalen HH" i Søren Kierkegaards Skrifter, bind 18 (2001), 123-42.

Kierkegaard, S. (1842-46), "Journalen JJ" i Søren Kierkegaards Skrifter, bind 18 (2001), 143-313.

Kierkegaard, S. (1843), Enten - Eller i Søren Kierkegaards Skrifter, bind 2-3 (1997).

Kierkegaard, S. (1844), Philosophiske Smuler i Søren Kierkegaards Skrifter, bind 4 (1997), 211-306.

Kierkegaard, S. (1844), Begrebet Angest i Søren Kierkegaards Skrifter, bind 4 (1997), 307-461.

Kierkegaard, S. (1844), Fire opbyggelige Taler i Søren Kierkegaards Skrifter, bind 5 (1998), 283-381.

Kierkegaard, S. (1846), Afsluttende uvidenskabelig Efterskrıft i Søren Kierkegaards Skrifter, bind 7 (2002).

Kierkegaard, S. (1846-47), "Journalen NB" i Søren Kierkegaards Skrifter, bind 20 (2003), 5-129. 
Kierkegaard, S. (1847), Opbyggelige Taler i forskjellig Aand i Søren Kierkegaards Skrifter, bind 8 (2004), 107-431.

Kierkegaard, S. (1847), Kjerlighedens Gjerninger i Søren Kierkegaards Samlede Varker, 2. udg., bind 9 (1927).

Kierkegaard, S. (1848), Christelige Taler i Søren Kierkegaards Samlede Varker, 2. udg., bind 10 (1928), 5-362.

Kierkegaard, S. (1849), "Yppersteprcesten" - "Tolderen" "Synderinden", tre Taler ved Altergangen om Fredagen i Søren Kierkegaards Samlede Varker, 2. udg., bind 11 (1929), 273-311.

Kierkegaard, S. (1849), "Journalen NB12" i Søren Kierkegaards Papirer, bind 10,1 (1924), s. 346-432, og bind 10,2 (1926), 5-55.

Kierkegaard, S. (1850), Indøvelse i Christendom i Søren Kierkegaards Samlede Voerker, 2. udg., bind 12 (1929), 7-286.

Kierkegaard, S. (1851), To Taler ved Altergangen om Fredagen i Søren Kierkegaards Samlede Varker, 2. udg., bind 12 (1929), 307-36.

Kierkegaard, S. (1909-48 / 1968-78), Søren Kierkegaards Papirer, udg. af P. A. Heiberg, V. Kuhr og E. Torsting, bd. I-XI, København; 2. forøgede udg. ved N. Thulstrup, bd. I-XVI, København.

Kierkegaard, S. (1920-36), Søren Kierkegaards Samlede Varker, udg. af A. B. Drachmann, J. L. Heiberg og H. O. Lange, 2. udg., bd. 115, København.

Kierkegaard, S. (1997-2004), Søren Kierkegaards Skrifter, udg. af Niels Jørgen Cappelørn, Joakim Garff, Johnny Kondrup et al., bind 1-8 og 17-21, København.

Möhler, J. A. (1827), Athanasius der Große und die Kirche seiner Zeit, bind 1-2, Mainz.

Rudelbach, A. G. (overs., 1825), Den rette uforandrede Augsburgske Troesbekjendelse med sammes, af Ph. Melanchthon forfattede, Apologie, København.

\section{Noter}

Denne artikel er en lettere bearbejdet udgave af et foredrag holdt ved Center for Grundtvigstudier, Aarhus Universitet, i efteråret 2003.

Irenæus' hovedværk omtales normalt under korttitlen Adversus haereses (Imod kæetterne). Grundtvig havde selvfølgelig værket i sit righoldige bibliotek; under nr. 659 i Fortegnelse over den af N. F. S. Grundtvig efterladte Bogsamling, som bortscelges ved offentlig Auction (København 1873), er opført: "S. Irenæi, Episc. Lugd. Contra omnes Hæreses Libri 
quinque [Mod alle Kættere i fem Bøger af Sankt Irenæus, biskop i Lyon], Oxoniæ [Oxford] 1702 (F)." Bogen, der er i folioformat, og som er udgivet og fyldigt kommenteret af J. E. Grabbe, har både en græsk og en latinsk titel; den latinske lyder i sin helhed: S. Irenoei / Episcopi Lugdunensis / Contra omnes Horeses / Libri quinque. Det er da også den udgave, jeg har lagt til grund for min samlæsning af Grundtvigs oversættelse med den latinske og delvis med den græske tekst.

2 Oversættelsen blev offentliggjort i Theologisk Maanedsskrift, udg. af A. G. Rudelbach, bd. 11 (København 1827), 10-61 og 193-282, med en indledning, 1-10, og forsynet med noter. Det er i indledningen, Grundtvig oplyser, at han "kun for fire Aar siden" læste Irenæus for første gang. Under titlen Om Kiødets Opstandelse og det evige Liv af Biskop Irenceus, fordansket genudgav Grundtvig sin oversættelse som selvstændig bog i 1855. Når titlen er ændret, skyldes det tilsyneladende, at han ønskede at markere, at den femte bog "omhandler vor tredie Troes-Artikel, og da navnlig 'Kiødets Opstandelse og det evige Liv'", som det hedder på førte side af det tosidet upaginerede forord. Samme sted oplyses det, at skønt han i 1854 har sammenholdt oversættelsen med grundteksten og rettet, hvad han fandt af fejl, er der kun tale om ubetydelige forandringer. Bogen er formentlig udkommet $\mathrm{i}$ april 1855; $\mathrm{i}$ al fald omtales den under "BogNyt" i Dansk Kirketidende, nr. 20, den 6. maj 1855, sp. 327-28. Her i artiklen citeres der efter Grundtvigs oprindelige oversættelse (der er i øvrigt ingen forskelle $\mathrm{i}$ ordlyden af kap. VI i forhold til den gennemsete genudgivelse).

Möhler var en af det 19. årh.s mest fremtrædende katolske teologer i Tyskland, og hans værk om Athanasius, som blev studeret af både katolske og protestantiske teologer, er en af det 19. årh.s væsentligste dogmehistoriske bidrag til kristologien. Modsat Grundtvig ejede Kierkegaard værket, jf. nr. 635-36 i Fortegnelse over Dr. Søren A. Kierkegaards efterladte Bogsamling som bortsalges ved offentlig Auction (København u.å. [1856]). Et væld af sirlige blyantsmarkeringer i dette eksemplar, som i dag står på Sorø Akademis bibliotek, vidner om, at Kierkegaard med stor opmærksomhed har læst bogen fra perm til perm.

Theologisk Maanedsskrift, 26 (1855-udgaven, 22).

Grundtvig har her en besværlig og spidsfindig note: "Secundum imaginem et similitudinem Dei, hvorved er at mærke, at Irenous ved imago forstaaer den legemlige, og ved similitudo den aandelige Lighed, istedenfor at vi, som oversætte: Billede og Lignelse, vel maa ordne det

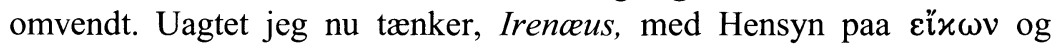

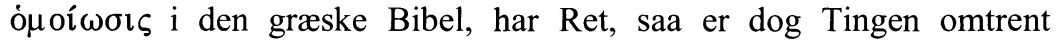
ligegyldig, naar vi kun huske, at $\varepsilon i ̋ \omega \nu$ og imago hos Kirke-Fædrene ei betyder hvad vi kalde Billede, men hvad vi kalde Lignelse, saa det er kun grov Misforstand, naar man siger, at de Gamle ved Guds Billede ei tænkde paa den aandelige Lighed; da de jo kalde ò $\mu$ oí $\omega$ oı $\varsigma$ og similitudo hvad vi, $i$ denne Sammenhoeng, kalde Billede." Jeg citerer først og fremmest noten for ikke at have fortiet den, for egentlig er jeg ikke helt klar over, hvad Grundtvigs ærinde er med den, især fordi jeg ikke ved, 
hvem notens "vi" er; det synes i al fald ikke at være den forståelse af billede og lighed, Grundtvig ellers benytter i sit senere forfatterskab. Jeg mener, man må læse Irenæus sådan, at imago er Guds billede i sjælen (og hverken 'den legemlige' eller 'den åndelige lighed') og similitudo Guds lighed $\mathrm{i}$ ånden (netop 'den åndelige lighed', som forbindes med legemet). Herom mere senere under referatet af Möhlers udlægning af Irenæus' menneskesyn.

Ibid., 27-28 (1855-udgaven, 23-24).

Ibid., 28 (1855-udgaven, 24).

Grundtvig gengiver flot 'plasma' med 'Konst-Værk' og tænker vel hermed på Gud som en kunstner, der danner eller former mennesket af jord, jf. 1 Mos 2,7. Ordet stammer fra græsk $\pi \lambda \alpha \dot{\alpha} \sigma \mu \alpha$ og betyder if. Liddell \& Scott "anything formed or moulded, image, figure", men kan også anvendes i betydningen "the body, as fashioned by the Creator"; desuden betyder det "formed style in writing or speaking". Som låneord på latin betyder det "noget som er dannet, f. E. af Leer. Deraf 1) (hos de christne Skrib.) et Menneske" if. J. Baden Latinsk-Dansk Lexicon eller Ordbog, bd. 1-3 (København 1786-88), som Grundtvig havde i sit bibliotek (nr. 2302-4). Jeg har første gang valgt betydningen 'det dannede legeme' og derefter blot 'legeme'.

Grundtvig gengiver fint 'substantiam carnis' med 'Kiød-Stoffet'.

10 Grundtvig udelader mærkelig nok udtrykket 'propter effusionem Spiritus', jf. den anførte udgave fra 1702 af Contra omnes Hoereses, 407. 1 Thess 5,23 .

12 Ibid., 28 (1855-udgaven, 24).

13 Möhler op.cit., 1, 65. I sit eksemplar (se note 3) har Kierkegaard med en kraftig blyantstreg i margen udhævet det her citerede. Citatet er fra femte bog, kap. 9. Her gengivet i Möhlers oversættelse (op.cit., 1, 65).

Citatet er fra fjerde bog, kap. 37. Her gengivet i Möhlers oversættelse og med hans fremhævelse (op.cit., 1, 65). Möhler op.cit., 1, 66ff.

17 I årene 1855 til 1861 lod Grundtvig en række afhandlinger offentliggøre i Kirkelig Samler. Et Tidsskrift til christelig Oplysning, udg. af Chr. M. Kragballe, bd. 1-7. Senere samlede og udgav han disse afhandlinger i bogen Den christelige Børnelaerdom (København 1868), som jeg i det følgende citerer fra.

Den christelige Børnelcerdom, 144.

Ibid., 146.

Ibid., 148.

Ibid., 149.

Ibid., 167.

Salmerne findes i udgaven Salmer og aandelige Sange, bd. 1-5 (København 1868-81); bd. 4, Kristen-Livet i Salme-Sang (1875). 
26

Efterklang kalder Grundtvig det direkte i salmen "Herrens Røst var over Vandet" i anden strofe:

- Herrens Røst var over Støvet,

Der han danned Mund af Muld,

End er ikke overdøvet

Efterklangen underfuld;

End den lever paa vor Tunge,

Naar som Mennesker vi sjunge:

'I Guds Billed skabtes vi.'

Ibid., nr. 6, 9-10; jf. DDS 2003, nr. 388 (gammelt nr. 346).

Ibid., nr. 5, 6-8.

Om der i udtrykket "et dunkelt Minde" ligger en reminiscens af platonismens erindring om menneskets guddommelige oprindelse, tør jeg ikke afgøre, men heller ikke afvise.

Salmen er skrevet af Johan Jacob Rambach i 1725, men gendigtende oversat af Brorson i 1734. Her citeret efter Hagen 1834, 146-48. Jf. DDS 2003, nr. 159 (gammelt nr. 140), hvor salmen er bearbejdet og forkortet.

Ibid., 17-18. Jf. DDS 2003, nr. 122 (gammelt nr. 98).

Det fremgår af den københavnske prædikantfortegnelse på forsiden af lørdagsudgaven af Adresseavisen.

Evangeliet til 12. søndag efter trinitatis, jf. Forordet Alter-Bog for Danmark (København 1830). Denne søndag faldt i 1839 på den 18. aug.

EE:171, i SKS 18 (2001), 59.

Se N. F. S. Grundtvig: Prodikener i Vartov. Bind 1 1839-40, udg. af Jette Holm, Elisabeth A. Glenthøj, Lars Toftdahl, Leif Kallesen og Johannes B. Glenthøj i samarbejde med Christian Thodberg (København 2003), 8082 .

Tydelige allusioner til Kristushymnen i Fil 2,6-11, som jeg skal komme tilbage til senere.

Refererer til ApG 17,28.

Alluderer til Grundtvigs salme "Min Mund og mit Hjerte", nr. 113 i Sang-Vark til den Danske Kirke, bd. 1 (København 1837), 289f. Jf. DDS 2003, nr. 396 (gammelt nr. 355).

Nr. 311 i Salmer og aandelige Sange, bd. 3, Kirke-Aaret $i$ Salme-Sang (København 1873), 406-08. Jf. DDS 2003, nr. 443 (gammelt nr. 376).

Notesbog 1:6, i $S K S 19$ (2001), 35. Fremhævelserne er mine.

Ibid., 23. Fremhævelsen er min.

Ibid., 24. Fremhævelsen er min.

Den rette uforandrede Augsburgske Troesbekjendelse med sammes, af Ph. Melanchthon forfattede, Apologie, overs. af A. G. Rudelbach (København 1825), 46-47.

Min lidt frie oversættelse, jf. Die Bekenntnisschriften der evangelischlutherischen Kirche. Herausgegeben im Gedenkjahr der Augsburgischen Konfession 1930, 11. udg. [ty./lat.], (Göttingen 1992), 434. Fremhævelsen er min for at understrege det, der er vigtigt i Kierkegaards kontekst.

44 2. del, 1, 11, jf. Die Bekenntnisschriften, 848. Fremhævelsen er atter min, jf. foregående note. 
2. del, 1, 57, jf. Die Bekenntnisschriften, 864 .

Se SKS 4 (1997), 332-36.

Den christelige Børneloerdom, 163.

Ibid., 223.

SKS 4 (1997), 365-66.

Ibid., 349.

En mere detaljeret redegørelse for det her omhandlede giver Arne Grøn i sin bog Begrebet angst hos Søren Kierkegaard (København 1993).

SKS 4 (1997), 354.

Ordene er fra Matt 10,28, der i 1819-oversættelsen af Det Nye Testamente lyder således i sin helhed: "Og frygter ikke for dem, som slaae Legemet ihiel, men kunne ikke slaae Sielen ihiel; men frygter hellere for den, som kan fordærve baade Siel og Legeme i Helvede."

NB:93, i $S K S 20$ (2003), 76.

Se Pap. VIII 2 B 170,5.

Jf. SKS 3 (1997), 203.

Den her parafraserede og udlagte tekst findes i $S K S 3$ (1997), 183-84.

Se $S K S$ 8 (2004), 107-250; 138.

Ibid., 363.

Se $S V 2$ 9, 242-56 og 82-83.

$\mathrm{HH}: 2$, i $S K S 18$ (2001), 125.

Ibid., 125-26.

Dansk Kirketidende, udg.af L. Helveg og C. J. Brandt, nr. 23-24, den 27. maj (1855), sp. 373. Jf. nr. 144 i Folkehøjskolens sangbog (1989).

Se SKS 4 (1997), 222-26.

Ibid., 227.

Se note 20 .

Den christelige Børnelardom, 142-43.

Ibid., 162.

Jf. fx den 73. strofe i 6. del af "Christenhedens Syvstjerne":

Derfor end os dybt kan røre

Det Guds-Ord, som os har skabt,

Naar vi af Guds Mund det høre,

At det bedste vi har tabt:

Barne-Lighed med vor Fader:

Sandheds Gud og Løgnens Hader,

Kiærlighedens Kildespring!

Dansk Kirketidende (1855), sp. 373. Jf. nr. 144, syvende strofe, i Folkehøjskolens sangbog (1989).

70 Citeret efter 1819-oversættelsen af Det Nye Testamente.

71 I den græske tekst anvendes to forskellige ord, først iøo (ísos), derefter ó $\mu$ oí $\omega \mu \alpha$ (homoíōma).

72 Salmer og aandelige Sange, bd. 4 (1875), 6-8.

73 Ibid., nr. 6, 9-10. 
Jf. fx anden strofe i nr. 16 "Hvor er nu vor Herres Grav": "I vor Daab til Herrens Død / Og Oprejsning derefter” (Salmer og aandelige Sange, bd. 4 (1875), 22).

Jf. fx femte strofe i nr. 15 "Udfrittes du, hvoraf vi veed":

Vi kan forstaa, at er det sandt,

Er Aanden her den rette,

Kan Daaben, med vor Pagt i Pant,

Vor Synde-Skyld udslette,

Da er vor Pagt, vor Tro og Daab

Saa gamle som det Himmel-Haab,

Der i vor Barm oprinder.

Salmer og aandelige Sange, bd. 4 (1875), 20.

Se SKS 8 (2004), 281-96.

Ibid., 289-90.

Ibid., 290.

If. dåbsritualet i Forordnet Alter-Bog for Danmark (1830) indledes dåben med en længere belæring af præsten. Jeg vil her særlig fremhæve to på hinanden følgende afsnit, da både Grundtvig og Kierkegaard reflekterer dem begge i deres opfattelse, mens Grundtvig dog prioriterer det første og Kierkegaard det andet. De to afsnit lyder: "Men at vi skulle faae Ret og Adgang til saadan Guds Naade i Christo, har han indstlftet Igienfødelsens og Fornyelsens Bad, som skeer ved den Hellig Aand, hvilken han udøser rigeligen over os formedelst Jesum Christum, vor Frelser, at vi skulle retfærdiggiøres ved hans Naade, og efter Haabet vorde Arvinger til det evige Liv. Thi Daaben er ikke Ureenligheds Aflæggelse paa Kiødet, men en god Samvittigheds Pagt med Gud formedelst Jesu Christi Opstandelse", 243 (fremhævelserne er mine).

Om Kierkegaards fremhævelse af den inderliggørende tilegnelse af dåben som helt afgørende for dens betydning for den døbte, se Afsluttende uvidenskabelig Efterskrift, i SKS 7 (2002), 49-51, 333-35 og 553-54.

Se nærmere om skriftemålets udvikling og om skriftemålsliturgien i første halvdel af det 19. årh. i min afhandling "Die ursprüngliche Unterbrechung. Søren Kierkegaard beim Abendmahl im Freitagsgottesdienst der Kopenhagener Frauenkirche", overs. af Krista-Maria Deuser, i Kierkegaard Studies: Yearbook 1996 (Berlin \& New York 1996), 315-88, især 356-74 (en kortere version på dansk er under titlen "Søren Kierkegaard til altergang om fredagen i Vor Frue Kirke" udkommet i Dansk Teologisk Tidsskrift 1/2000, 1-35). Det må her erindres, at Kirkeritualet fra 1685 bestemmer, at de, "som ville bruge det hellige Nadverens Sacramente, skulle enten Dagen tilforn, eller samme Dag for [før] Prædiken, om det for vigtige Aarsager ikke kand skee Dagen tilforn, indstille sig for Præsten i Skriftestolen, bekiende deres Synder for hannem og bede om Afløsning" (4. kap., art. 1, citeret efter 1762-udgaven). Sådan havde det ikke altid været. Det vil sige, skriftemål havde den lutherske kirke haft lige siden reformationens dage, men som et frivilligt tilbud til de ængstede samvittigheder, ikke som et krav. Det var først med Kirkeritualet, at skriftemål blev gjort til en uomgængelig 
betingelse for at kunne deltage i nadveren. Og skønt der var indført visse liturgiske ændringer ved kongelige forordninger og reskripter, og skønt der var opstået et væld af forskellige liturgiske nydannelser ved skik og brug - og ved selvtægt, var Kirkeritualet principielt set stadig gældende på Grundtvigs og Kierkegaards tid, også hvad den bestemmelse angår.

Se nr. V i "Taler ved Altergang om Fredagen", fjerde afdeling af Christelige Taler i SV2 10, 342; nr. II i "Yppersteprasten" - "Tolderen" - "Synderinden", tre Taler ved Altergangen om Fredagen i SV2 11, 299; og nr. II i To Taler ved Altergangen om Fredagen i SV2 12, 331.

Se nr. II i “Yppersteprasten" - "Tolderen" - "Synderinden", i SV2 11, 299.

Se nr. II i "Taler ved Altergang om Fredagen" i SV2 10, 318.

Dette forekommer i flere af Kierkegaards taler ved altergang om fredagen og synes at forudsætte, at de er tænkt holdt, mellem skriftemålet og altergangen, i Vor Frue Kirke med Thorvaldsens Kristusstatue som altertavle. Og Thorvaldsen havde netop med figurens stilling og bevægelse ønsket at få det frem, at Kristus elsker og omfavner menneskene og indbyder dem med sit "Kommer hid", som der står på statuens fodstykke; se nærmere herom i min artikel i Dansk Teologisk Tidsskrift, 32. Se nr. III i "Taler ved Altergang om Fredagen" i SV2 10, 320-21.

Se nr. I i "Yppersteprasten" - "Tolderen" - "Synderinden" i SV2 11, 289-90, og nr. II i To Taler ved Altergangen om Fredagen i SV2 12, 33334.

Se nr. II i “Ypperstepraesten" - "Tolderen”- "Synderinden, i SV2 11, 299-300.

Se nr. III i “Yppersteprasten" - "Tolderen" - "Synderinden" i SVV2 11, 310.

Se nr. I i To Taler ved Altergangen om Fredagen i SV2 12, 318 og 325.

Se nr. V i “Taler ved Altergang om Fredagen"i SV2 10, 342-43.

Se nr. I i To Taler ved Altergangen om Fredagen i SV2 12, 318.

Se nr. III i "Taler ved Altergang om Fredagen" SV2 10, 322-23.

Se nr. I i "Taler ved Altergang om Fredagen" i $S V 2$ 10, 298.

Se nr. I i Taler ved Altergangen om Fredagen i SV2 12, 319. Denne sorg efter Gud er også et tilbagevendende tema i den lange skriftemålstale $\mathrm{i}$ første del af Opbyggelige Taler iforskjellig Aand.

Se den sidste af de tre taler ved altergang om fredagen, som Kierkegaard holdt i Vor Frue Kirke, og som han lod Anti-Climacus optage i tredje del, "Fra Høiheden vil han drage Alle til sig", af Indøvelse $i$ Christendom, i SV2 12, 177.

Se nr. I i Taler ved Altergangen om Fredagen, i SV2 12, 325.

Se Den christelige Børneladom, 219-26.

Jf. Den christelige Børnelardom, 166: "i den Helligaands Kraft bliver Daaben et Gienfødelsens Bad og bliver Nadveren et evigt Levebrød for det i Guds Billede skabte, dybt faldne, men ligesaa høit opreiste Menneske". 
100 Salmer og aandelige Sange, bd. 3 (1874), nr. 120, 144. Jf. strofe tre i den forkortede udgave i DDS 2003, nr. 608 (gammelt nr. 537).

101 Ibid., nr. 50, 48. Jf. DDS 2003, nr. 132 (gammelt nr. 108).

102 Ibid., nr. 345, 454-56. Jf. den forkortede udgave i DDS 2003, nr. 609 (gammelt nr. 540).

103 SKS 5 (1998), 316.

104 Ibid., 296.

105 Ibid., 329.

106 SKS 8 (2004), 351.

107 Pap. X 1 A 605.

108 Se SKS 7 (2002), 521.

109 SKS 18 (2001), 302. 